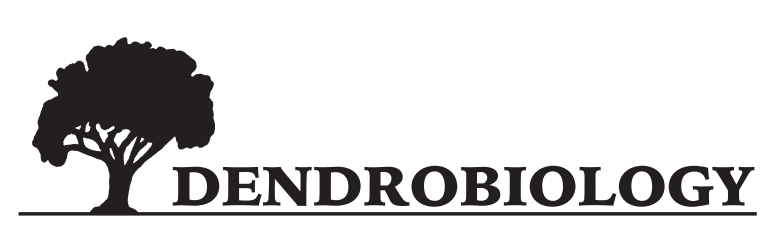

2020, vol. $83,1-19$

http://dx.doi.org/10.12657/denbio.083.001

\author{
Zdeněk Vacek, Stanislav Vacek, Anna Prokůpková, Daniel Bulušek, \\ Vilém Podrázský, Iva Hůnová, Tereza Putalová, Jan Král
}

\title{
Long-term effect of climate and air pollution on health status and growth of Picea abies (L.) Karst. peaty forests in the Black Triangle region
}

\author{
Received: 10 December 2019; Accepted: 16 March 2020
}

\begin{abstract}
The Jizerské hory Mts. (the Czech Republic) are part of the Black Triangle region strongly affected by a decline and dieback of Norway spruce (Picea abies [L.] Karst.) stands since the 1970s. In the studied peaty spruce stands in the summit parts of the Jizerské hory Mts., the health status, radial growth and foliar nutrient content in relation to air pollution $\left(\mathrm{SO}_{2}, \mathrm{NO}_{\mathrm{x}}\right.$ and $\left.\mathrm{O}_{3}\right)$ and climate factors (temperature, precipitation) were investigated in 1960-2015. A considerable disturbance of the stand structure induced by an increased mortality was observed in 1981-1983 when more than a half of the tree individuals died. Severe defoliation occurred in 1981 as a consequence of the synergic effects of air pollution, winter desiccation and spruce bark beetle outbreak, as well as in 2015 due to the drought and high temperatures. Tree ring analyses indicated significant growth depression in 1979-1987, a period of the highest $\mathrm{SO}_{2}$ load, and in 2010-2015. Foliation and diameter increment were significantly influenced by $\mathrm{SO}_{2}$ and $\mathrm{NO}_{\mathrm{x}}$ concentrations, the maximum daily concentration being the most negative factor; no significant correlation of the ozone exposure was detected, though. Foliar analyses also document significant negative impacts of air pollutants on the nutrient status of forest stands, mainly in the increase of the sulphur level. Since 1990, a significant increase in calcium and magnesium has been observed, as a result of forest liming. Interaction between radial growth and temperature was stronger compared to precipitation. Low temperatures and high precipitation in growing season were the limiting factors for radial growth in waterlogged mountain areas.
\end{abstract}

Keywords: Norway spruce, air pollutants, climate factors, nutrients, stress factors, Czech Republic

Addresses: Z. Vacek, S. Vacek, A. Prokůpková, D. Bulušek, V. Podrázský, T. Putalová, J. Král, Czech University of Life Sciences Prague, Faculty of Forestry and Wood Sciences, Kamýcká 129, 16951 Prague 6 - Suchdol, Czech Republic, e-mail: vacekz@fld.czu.cz

I. Hůnová, Czech Hydrometeorological Institute, Na Šabatce 2050/17, 14306 Prague 412 - Komořany, Czech Republic

\section{Introduction}

In Central Europe, spruce stands are dominant in mountain regions (Staszewski et al., 2012; Sharma et al., 2017, 2018; Štícha et al., 2019). The impact of air pollutants on mountain spruce forests was revealed in the 1950s and it culminated from the 1970s to the 1990s (Modrzyński, 2003; Máliš et al., 2010) persisting, to a lesser extent, until now (Vacek et al., 2012, 2016). The impacts of an extensive decline of 
forests in the Sudetes mountain range and especially in the Black Triangle region will remain apparent for many decades (Lorenz et al., 2008; Vacek \& Matějka, 2010; Slanař et al., 2017). A boom of the power industry near the borders of Germany, the Czech Republic and Poland together with the prevailing western winds resulted in a considerable increase in air pollution stress in the region of interest - the Jizerské hory Mts., Krkonoše Mts. and Orlické hory Mts. (Błaś et al., 2008; Zahradník et al., 2010; Vacek et al., 2013; Král et al., 2015). Vast areas (21,000 ha) of mostly spruce forests situated above $1,000 \mathrm{~m}$ a.s.l. were damaged by increased $\mathrm{SO}_{2}$ levels (Vacek et al., 2003). At that time, the Czech Republic belonged among regions with the highest levels of acid deposition in Europe (Hůnová et al., 2004; Borůvka et al., 2005). The Polish part of the Sudetes mountains faced a similar substantial damage to forest stands (Slovik et al., 1995; Modrzyński, 2003). Substantial local damage to spruce stands also occurred in the Šumava Mts. (Vacek et al., 2006, 2009, 2019a; Krejčí et al., 2013).

The Jizerské hory Mts. were among the localities that suffered the most severe damage (Šrámek et al., 2008). Pollution effects slowed down the growth and often caused complete disintegration of stands (Vacek et al., 2003). There was a marked decrease in sulphur dioxide concentration in the 1990s (Lomský \& Srámek, 2002). In subsequent years the health status of forest stands gradually improved while currently, a significant loss due to sulphur dioxide is improbable (Lomský et al., 2012). The improved condition of the forests since the early 1990s was demonstrated by several studies that confirmed an increase in the stand growth (Vacek et al., 2015; Putalová et al., 2019).

However, higher increments in mountain forest stands may relate to the climate change, especially to the rising temperature as a consequence in recent years (Lindner et al., 2010). This statement was confirmed in Austria by Petritsch and Hasenauer (2009) who reported an average extension of growing seasons since 1960 by 0.34 day per year. Other factors that influence the growth of forest stands and, at the same time, relate to the climate change include changes in total precipitation, increase in the temperature and atmospheric $\mathrm{CO}_{2}$ (Churkina et al., 2007; Eastaugh et al., 2011), and increased N deposition (de Vries et al., 2009). These factors, however, do not always necessarily lead to higher growth; sometimes a decrease can occur (Etzold et al., 2014) even though the growth model studies confirm an increase in the forest stand productivity in the future (Meehl et al., 2007). Nevertheless, there are numerous stochastic phenomena that exert a negative influence on the stand health, very difficult to predict in the future, such as an increase in the ozone level, sulphur deposition or frequency of abiotic and biotic disturbances (Schelhaas et al., 2002; Braun et al., 2010; Cukor et al., 2019a). Among them, due to the warming, the extension of the growing period and the risk of bark beetle disturbances, there is a markedly negative factor for Norway spruce (Grundmann et al., 2011).

On the other hand, it is to note that forest ecosystems mitigate the impacts of climate changes because they, for example, balance the water regime (Alewell \& Bebi, 2011) or decrease the impact of natural risks (Brang et al., 2006) or cool down the regional climate (Renaud \& Rebetez, 2009). In addition, the reaction of forests to environmental changes differs in relation to the type of forest, species composition and habitat conditions, because in an extremely warm year the growth may be reduced in the lowlands, while it may be accelerated at higher altitudes (Jolly et al., 2005; Etzold et al., 2014). The growth of forest stands can be considered as a sensitive indicator of forest vitality and ability to buffer environmental changes (Dobbertin, 2005). Due to the changing climate, changes in the ecophysiological processes of the tree growth influence the competitiveness of particular species (van der Meer et al., 2002), which subsequently causes changes in the long-term forest dynamics (Ge et al., 2011).

In more detail, the growth of a tree depends on carbon assimilation which requires resources such as light, water, nutrients and atmospheric $\mathrm{CO}_{2}$ (Kirschbaum, 2000). In the context of global warming, an increasing atmospheric $\mathrm{CO}_{2}$ content increases photosynthetic production and the subsequent tree growth (Ge et al., 2011). But this effect can be neutralized and reversed by drought and nutrient deficiency stress (Bergh et al., 2005). So, the changes in hydrological processes in forest ecosystems of the temperate zone, including mountain spruce forest of Central Europe, can influence these forests in different ways (Bonan, 2008). Nevertheless, the impacts of climate changes on these forest ecosystems and on soil moisture availability and the subsequent growth have not been investigated sufficiently, yet.

Scientific literature addressing the impacts of climate changes on forest stand growth often covers research based on model plots (Lindner et al., 2010; Thiele et al., 2017), but research studies on a regional or national level have still been scarce (Campioli et al., 2012). The number of published papers on the impacts of climate change on the growth of spruce has been increasing, though, in Europe (Klisz et al., 2017; Vitali et al., 2017; Vacek et al., 2019b; Mikulenka et al., 2020). However, the studies on the issues of the growth and health of peaty and waterlogged spruce forests are very scarce in comparison to climax spruce forests (Vacek et al., 2013; Putalová et al., 2019). The existing studies mainly focus 
on assessing the radial growth and health status of spruce trees based on the tree-ring dating, classification of defoliation, symptoms of yellowing of foliage or foliar nutrition analyses (Mäkinen et al., 2003; Podrázský et al., 2005; Král et al., 2015; Cukor et al., 2019b; Putalová et al., 2019). These studies show that peaty spruce forests are more vulnerable to the air pollution load and climatic stress compared to climax spruce forest, while peaty stands show slightly better resistance in terms of bark beetle outbreaks. Peaty spruce research mostly deals with the physical and chemical parameters of the soil in relation with climate change (increased air temperature, drop in the water level), especially in terms of the carbon cycle (Krassovski et al., 2015; Griffiths \& Sebestyen, 2016; Fernandez et al., 2019; McPartland et al., 2019).

The objective of this study is to determine the effect of air pollution and climate changes on the health status and growth of peaty spruce stands, in the framework of a long-term research in the Black Triangle region of the Czech Republic. The objectives were to determine: (1) long-term trends of air pollution indicators, climatic factors, health status, nutrient concentrations in the foliage and productivity of peaty Norway spruce stands; (2) the effect of $\mathrm{SO}_{2}$, $\mathrm{NO}_{\mathrm{X}}$ and $\mathrm{O}_{3}$ concentrations on the dynamics of foliation and radial growth of spruce; (3) the impact of temperatures and precipitation on diameter increment of spruce in relation to climatic changes and (4) the relations between the air pollution, climate, health status and productivity of peaty spruce stands.

\section{Material and methods}

\section{Study area}

The study was conducted on four permanent research plots (PRP) in the Jizerské hory Protected Landscape Area in the north of the Czech Republic, in a part of the Black Triangle region (Fig. 1). The PRP are located in three small-scale particularly protected territories of peat bogs - Rybí loučky Nature Reserve (NR), Rašeliniště Jizery National Nature Reserve (NNR) and Rašeliniště Jizerky NNR. The Rybí loučky NR lies in the headwater area of the Rybí potok brook at an altitude of $840 \mathrm{~m}$ a.s.l. The territory of 37.91 ha has been protected since 1965 . The Rašeliniště Jizery NNR is situated in a flat broad valley of the Jizera River on the border with Poland. The territory of 189.11 ha at an altitude of $850 \mathrm{~m}$ a.s.l. has been protected since 1960. The Rašeliniště Jizerky NNR is situated in a flat broad valley along the Jizerka stream at an altitude of $865 \mathrm{~m}$ a.s.1. The territory of 112.21 ha has been protected since 1960 . Four PRP of 0.25 ha in size $(50 \times 50 \mathrm{~m})$ were established by theodolite in 1980 and repeated measurements (height, diameter, crown, coordinates) were taken by the Field-map technology (IFER - Monitoring and Mapping Solutions, Ltd.) in 2015.

The study territory has a subarctic climate characterised by long, usually very cold winters, and short, cool to mild summers (Dfc) by Köppen climate classification (Köppen, 1936), or, by the detailed region Quitt distribution (Quitt, 1971), it is a
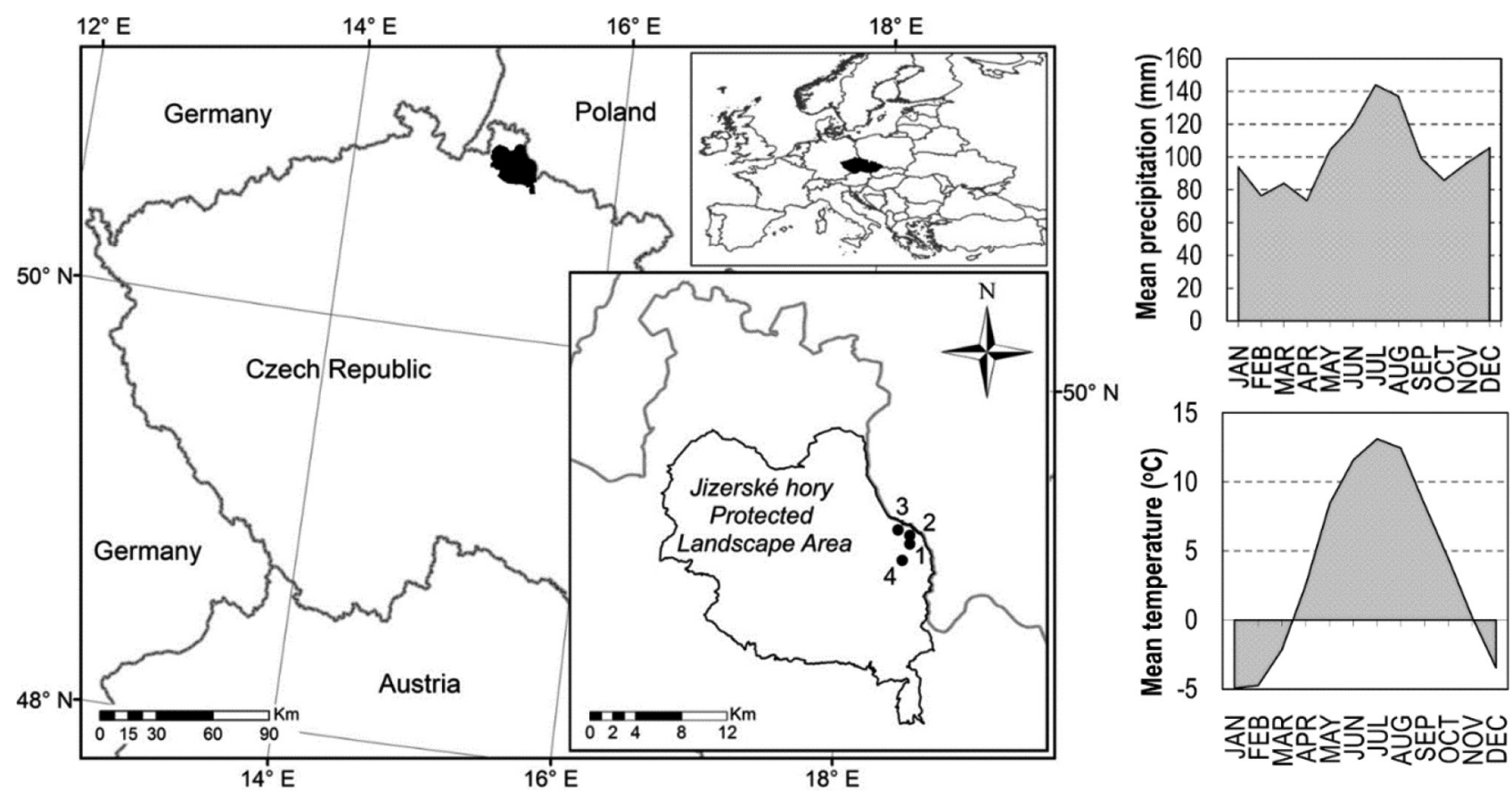

Fig. 1. Localization of peaty spruce stands on the permanent research plots 1-4 in the Jizerské hory Protected Landscape Area and mean monthly climate values (1960-2015) 
Zdeněk Vacek et al.

Table 1. Overview of the basic site and stand characteristics of the permanent research plots 1-4 in 1980 and 2015

\begin{tabular}{|c|c|c|c|c|c|c|c|c|c|c|c|}
\hline ID & Name of PRP & $\begin{array}{c}\text { GPS } \\
\text { coordinates }\end{array}$ & $\begin{array}{l}\text { Altitude } \\
\text { (m) }\end{array}$ & $\begin{array}{l}\text { Peat depth } \\
\min / \mathrm{max} \\
(\mathrm{cm})\end{array}$ & Year & $\begin{array}{l}\text { Age of tree } \\
\text { layers (y) }\end{array}$ & $\begin{array}{c}\varnothing \\
\text { diameter } \\
(\mathrm{cm})\end{array}$ & $\begin{array}{c}\varnothing \\
\text { height } \\
(\mathrm{m})\end{array}$ & $\begin{array}{c}\text { Stand } \\
\text { density } \\
\left(\text { trees ha }{ }^{-1}\right)\end{array}$ & $\begin{array}{c}\text { Basal } \\
\text { area } \\
\left(\mathrm{m}^{2} \mathrm{ha}^{-1}\right) \\
\end{array}$ & $\begin{array}{c}\begin{array}{c}\text { Stand } \\
\text { volume } \\
\left(\mathrm{m}^{3} \mathrm{ha}^{-1}\right)\end{array} \\
\end{array}$ \\
\hline \multirow[t]{2}{*}{1} & Rybí loučky 1 & $50^{\circ} 50^{\prime} 39^{\prime \prime} \mathrm{N}$ & 850 & $141 / 210$ & 1980 & 110 & 17.1 & 10.5 & 732 & 16.8 & 108 \\
\hline & & $15^{\circ} 20^{\prime} 29^{\prime \prime} \mathrm{E}$ & & & 2015 & $145 / 35 / 15$ & 7.2 & 4.7 & 1832 & 7.5 & 18 \\
\hline \multirow[t]{2}{*}{2} & Rybí loučky 2 & $50^{\circ} 50^{\prime} 42^{\prime \prime} \mathrm{N}$ & 845 & $155 / 245$ & 1980 & 110 & 19.5 & 11.2 & 676 & 20.2 & 139 \\
\hline & & $15^{\circ} 20^{\prime} 31^{\prime \prime} \mathrm{E}$ & & & 2015 & $145 / 35 / 15$ & 6.7 & 4.4 & 2892 & 10.2 & 17 \\
\hline \multirow[t]{2}{*}{3} & Rašeliniště & $50^{\circ} 51^{\prime} 11 " \mathrm{~N}$ & 835 & $127 / 196$ & 1980 & 90 & 18.6 & 10.5 & 880 & 23.9 & 136 \\
\hline & Jizery & $15^{\circ} 19^{\prime} 47^{\prime \prime} \mathrm{E}$ & & & 2015 & $125 / 35 / 15$ & 6.9 & 4.3 & 1484 & 5.5 & 10 \\
\hline \multirow[t]{2}{*}{4} & Rašeliniště & $50^{\circ} 49^{\prime} 37^{\prime \prime} \mathrm{N}$ & 870 & $168 / 230$ & 1980 & 55 & 14.5 & 8.4 & 1104 & 18.3 & 84 \\
\hline & Jizerky & $15^{\circ} 19^{\prime} 35^{\prime \prime E}$ & & & 2015 & $90 / 35 / 15$ & 12.4 & 5.7 & 796 & 9.5 & 37 \\
\hline
\end{tabular}

cold climatic region and subregion $\mathrm{CH} 4$ (very short, cold and humid summers; very long and cold winters with long-term snow cover). Long-term average annual temperatures at the nearby Jizerka meteorological station are around $3.8^{\circ} \mathrm{C}$, January temperatures are around $-5.0^{\circ} \mathrm{C}$ and temperatures in the month of July are around $13.1{ }^{\circ} \mathrm{C}$ (Fig. 1). The total annual sum of precipitation at the Jizerka ombrometric station reaches around $1,300 \mathrm{~mm}$. The duration of snow cover is usually more than 150 days per year and its depth exceeds $150 \mathrm{~cm}$. The investigated area is one of the coldest in the Czech Republic (Vesecký et al., 1991; Tolasz et al., 2007).

In the studied territory, peaty spruce stands of the association Sphagno-Piceetum (Tüxen 1937) Hartmann 1953 are clearly dominant, while the occurrence of waterlogged spruce stands of the association Bazzanio-Piceetum (Br.-Bl. et Sissingh 1939) and dwarf pine stands of the association Pino mugo-Sphagnetum (Kästn. et Flöss. 1933) are abundant (Rybníček, 2000). Forest site type belongs to 8R (Raised Bog Spruce) - Piccetum turfosum montanum (Viewegh et al., 2003). The species composition of these spruce stands is dominated by Norway spruce (Picea abies [L.] Karsten), with admixed dwarf pine (Pinus mugo Turra), and interspersed white birch (Betula pubescens Ehrh.), Carpathian birch (Betula carpatica Waldstein et Kitaibel) and rowan (Sorbus aucuparia L.).

The bedrock is composed of porphyric, medium-grained granite or granodiorite of the Krkonoše-Jizerské hory granite pluton which is overlaid by quaternary sediments. The prevailing soil type is fibric Organosol, less frequent are gleyic Organosol, histic Podzol and histic Gleysol (Vacek et al., 2003). The depth of the peat (T horizon) on the PRP was $127-168 \mathrm{~cm}$ in the forest stands (from soil pits) with the deepest peat in the forest-free area of $196-245 \mathrm{~cm}$ (from the peat sampler). Table 1 shows the basic characteristics of the PRP.

The territory of interest has been exposed to acid deposition environmental pollution for a long time. The heavy air pollution stress in the 1970s caused an extensive decline of the studied stands, and subsequent mass outbreaks of spruce bark beetle (Ips typographus; Vacek et al., 2013). Sulphur dioxide emissions from large thermal power plants around the town of Zittau in the territory of Germany and Poland were considered as the main cause (Matějka et al., 2010). The quantity of emissions increased more than ten times in the course of two decades $(45,000$ tons of emissions in $1957,500,000$ tons of emissions in 1980) - (Jirgle et al., 1983). The destruction of forest stands increased proportionately to the quantity of emissions. In the $1980 \mathrm{~s} \mathrm{ca} .12,000$ ha of dying and dead forest stands were gradually felled in the summit parts of the Jizerské hory Mts. above 900 m a.s.l. (Vacek et al., 2003).

\section{Data collection}

The health status of spruce stands was evaluated by their foliation (the term describing the amount of foliage/needles) and degrees of defoliation/needle loss (the term describing the relative loss of foliage) on 183-276 trees (with diameter at breast height $\geq 7$ $\mathrm{cm}$ ) in terms of the tree density on four PRP. In the period of 1980-1985, the health status of forest stands was evaluated every year by the foliation of particular trees. In 1985-2015, the evaluation was done in fiveyear intervals. The classification of spruce foliation is based on the concept of Tesař and Temmlová (1971). Average foliation of a stand is expressed as the arithmetical mean of the values of foliation of all trees on a plot and of the living trees. Defoliation (a complement of foliation to $100 \%$ ) with special respect to the coenotic position and morphological type of crown was estimated to the nearest $5 \%$. This method is practically identical with the methodology of the international project ICP-Forests and ICP-Focus (Lorenz, 1995). For further calculations, the degrees of defoliation were transformed to percentages of defoliation (average values for a given degree of defoliation). The assessment of the health status of spruce trees was based on the trend of the arithmetical mean of foliation of all trees and living trees on PRP, standard deviation of defoliation and on the number of dead trees (totally defoliated trees). For the overall assessment of the stand condition, total means of 
foliation of all trees including totally defoliated trees were computed.

Concentrations of nitrogen $(\mathrm{N})$, phosphorus $(\mathrm{P})$, potassium $(\mathrm{K})$, calcium $(\mathrm{Ca})$, magnesium $(\mathrm{Mg})$, sulphur $(\mathrm{S})$ and silicon $(\mathrm{Si})$ were determined by an analysis of foliage/needle samples (term used with reference to foliar sample characteristics). Samples were randomly (RNG function in Excel) taken from 7 trees on each PRP from the current needles in the third whorl of 4 branches of the illuminated part of the tree crown. All values were determined in \% of the air-dried sample at the room temperature. The material was decomposed in $\mathrm{H}_{2} \mathrm{SO}_{4}+\mathrm{H}_{2} \mathrm{O}_{2}$ and the respective values were determined by atomic absorption spectrometry (AAS) and spectrophotometry (Vacek et al., 2009). This methodology is compatible with the ICP Forests programme (UNECE, 2005).

Increment cores were randomly (RNG function in Excel) taken from 30 living dominant and co-dominant trees on each PRP (24-29 samples used for analysis) in autumn 2016 using a Pressler auger at breast height $(1.3 \mathrm{~m})$ perpendicularly to the axis of the stem (north-south direction). Annual ring widths were measured with an accuracy of $0.01 \mathrm{~mm}$ by an Olympus binocular microscope on the LINTAB measuring table and recorded with TsapWin software (Rinntech).

Stress factors related with air pollution and climate were derived using the data from air pollution monitoring stations and meteorological stations. Air pollution situation in the Jizerské hory Mts. region in terms of $\mathrm{SO}_{2}$ concentration was analysed using available data from the Jizerka station of the Research Institute of Forest and Game Management (VÚLHM) (858 m a.s.l.; GPS 5049'07"N, 15²0'44"E) situated in the summit parts of the Jizerské hory Mts. nearby the studied PRP. As the time series of measurements is short and $\mathrm{NO}_{\mathrm{x}}$ and $\mathrm{O}_{3}$ (exposure index AOT40F for forests) are not recorded there, the research team also used data from the Desná-Souš station in the Jizerské hory Mts. of the Czech Hydrometeorological Institute (ČHMÚ) (772 m a.s.l.; GPS $\left.50^{\circ} 47^{\prime} 21^{\prime \prime} \mathrm{N}, 15^{\circ} 19^{\prime} 11^{\prime \prime} \mathrm{E}\right)$, located 6-9 $\mathrm{km}$ from the PRP. $\mathrm{SO}_{2}$ data from the Bedřichov station of ČHMÚ (777 m a.s.l.; GPS $\left.50^{\circ} 47^{\prime} 28^{\prime \prime} \mathrm{N}, 15^{\circ} 08^{\prime} 33^{\prime \prime} \mathrm{E}\right)$ were also used. Both average annual and maximum daily values of concentrations in $\mu \mathrm{g} \mathrm{m}^{-3}$ were employed for evaluation. Climate behaviour evaluation with regard to temperature and precipitation conditions was based on the data from the Bedrichov $(777 \mathrm{~m}$ a.s.l.; GPS $\left.50^{\circ} 47^{\prime} 28^{\prime \prime} \mathrm{N}, 15^{\circ} 08^{\prime} 33^{\prime \prime} \mathrm{E}\right)$ and Jizerka meteorological stations (858 m a.s.l.; GPS $50^{\circ} 49^{\prime} 07^{\prime \prime} \mathrm{N}$, $\left.15^{\circ} 20^{\prime} 44^{\prime \prime} \mathrm{E}\right)$. The trend of temperature and precipitation conditions was studied using the data on the average annual temperature, temperature in the growing season (April-September), temperature in particular months, total annual precipitation, total precipitation in the growing season and monthly precipitation. Water (moisture) balance was calculated by Thornthwaite and Mather (1957) method.

\section{Data processing}

Tree ring increment series were individually crossdated (to remove errors related to missing tree rings occurrence) using statistical tests in the PAST 4 application (Knibbe, 2007) and subsequently they were subjected to visual inspection by Yamaguchi (1991) method. If a missing tree ring was identified, a tree ring of $0.01 \mathrm{~mm}$ in width was inserted in its place. Each measured dendrochronological sample was detrended by negative exponential detrending with added smoothing spline in the ARSTAN programme (Tree Ring Laboratory). Smoothing spline had $1 / 3$ age for each tree. This method focuses on the removal of the age-related trend while it preserves low frequency of climatic effect (Cook \& Kairiukstis, 1990). The detrended ring-width data were used to compute the expressed population signal (EPS). The EPS indicates the reliability of a chronology as a fraction of the joint variance of the theoretical infinite tree population (Fritts, 1976). The mean, maximum, minimum and standard deviation for the analysed ring widths were also computed for each PRP. An analysis of negative pointer years was conducted by Schweingruber et al. (1990). For each tree, the pointer year was defined as an extremely narrow tree ring that does not reach $40 \%$ of the average of increments from four preceding years. A negative year was identified if such a strong increment reduction occurred at least in $20 \%$ of trees on the plot. The mean standardized tree-ring width chronology from the PRP were correlated with climate data (precipitation, temperatures; 1960-2015) and air-pollution data ( $\mathrm{SO}_{2}$ concentrations; 1960-2015) from the Desná-Souš station. To express the relation between the diameter increment (ring width index) and climate characteristics (monthly air temperature and monthly sum of precipitation from May of the previous year to August of the relevant year) the DendroClim software was used (Biondi \& Waikul, 2004).

The data from the assessment of foliation, mortality, nutrient concentrations in the foliage, ring width index (RWI) and their relations to climate and air-pollution data were processed by the Statistica 12 (StatSoft, Tulsa). Differences between the time series (before, during and after the air pollution load) in the nutrient concentrations in the foliage, foliation of spruce and ring width index were tested separately by a one-way analysis of variance (ANOVA). The significantly different results were then tested by the post-hoc HSD Tukey test. In addition, the effect of air pollution data on the diameter increment 
and nutrient concentrations and foliation with time were tested by the Pearson correlation coefficient. To determine the combined effect of the average temperature and sum of precipitation in the current year and in the growing season on the diameter increment of spruce, a correlation quadratic model was used. The correlations between particular variables were tested at a significance level of $\alpha=0.05$. Variances are shown by standard deviation ( \pm SD). An unconstrained principal component analysis (PCA) in Canoco 5 programme (ter Braak \& Šmilauer, 2012) was used to analyse the relations between precipitation, temperature, $\mathrm{SO}_{2}$ concentrations and ring width in order to reveal similarity of all records during the time. Data were log-transformed, centred and normalized before the analysis.

\section{Results}

\section{Climatic and air-pollution conditions}

Long-term climate measurements at the Bedřichov station indicate considerable warming and decrease in total annual precipitation (Fig. 2). The graph illustrates an upward trend of average annual temperatures in $1960-2015$ by ca. $1.9^{\circ} \mathrm{C} / 56$ years, and an upward trend by ca. $2.2{ }^{\circ} \mathrm{C} / 56$ years per growing season. Total annual precipitation was moderately decreasing by $14 \mathrm{~mm} / 56$ years while total precipitation per growing season was increasing by $26 \mathrm{~mm} / 56$ years. Annual precipitation totals, particularly, largely fluctuated in the studied years. Total precipitation per growing season showed a similar trend. Water balance in period V-VIII shows an inconsiderable increase in the linear trend by $3 \mathrm{~mm} / 56$ years. This trend was influenced mainly by the year 2010 due to a very high water balance (2.4 times higher than the limit value of $300 \mathrm{~mm}$ ). In the studied period, the years 1963, 1972, 1982, 1990, 1991, 2003, 2014 and 2015 were relatively dry years, while the years 1982 , 2003 and 2015 were below the recognized limit.

In relation to sulphur dioxide stress, average annual concentrations of $\mathrm{SO}_{2}$ culminated at the studied stations in 1985-1990, when they were in the range of $19.2-57.4 \mu \mathrm{g} \mathrm{m}^{-3}$ with the maximum value at Bedřichov in 1987 (Fig. 3). Very high maximum daily concentrations of $\mathrm{SO}_{2}$ culminated in 1982-1992 at the studied stations, when they were from 92 to $1,000 \mu \mathrm{g} \mathrm{m}^{-3}$ with the maximum value at Bedrichov in 1987.

The ozone exposure indices AOT40F for forests were relatively high in the studied years with a pronounced peak in 2003 reaching the value of 55,825 $\mathrm{ppb} \mathrm{h}^{-1}$ AOT40F (Fig. 4). This index exceeded the value of 40,000 $\mathrm{ppb} \mathrm{h}^{-1}$ also in 1997, 1998, 2002 and 2006. The trend of $\mathrm{NO}_{\mathrm{x}}$ concentration shows a decreasing tendency with the maximum of $17.2 \mu \mathrm{g} \mathrm{m}^{-3}$ in 1994, which it stabilized at value of $7.4 \mu \mathrm{g} \mathrm{m}^{-3}$ in 2012.

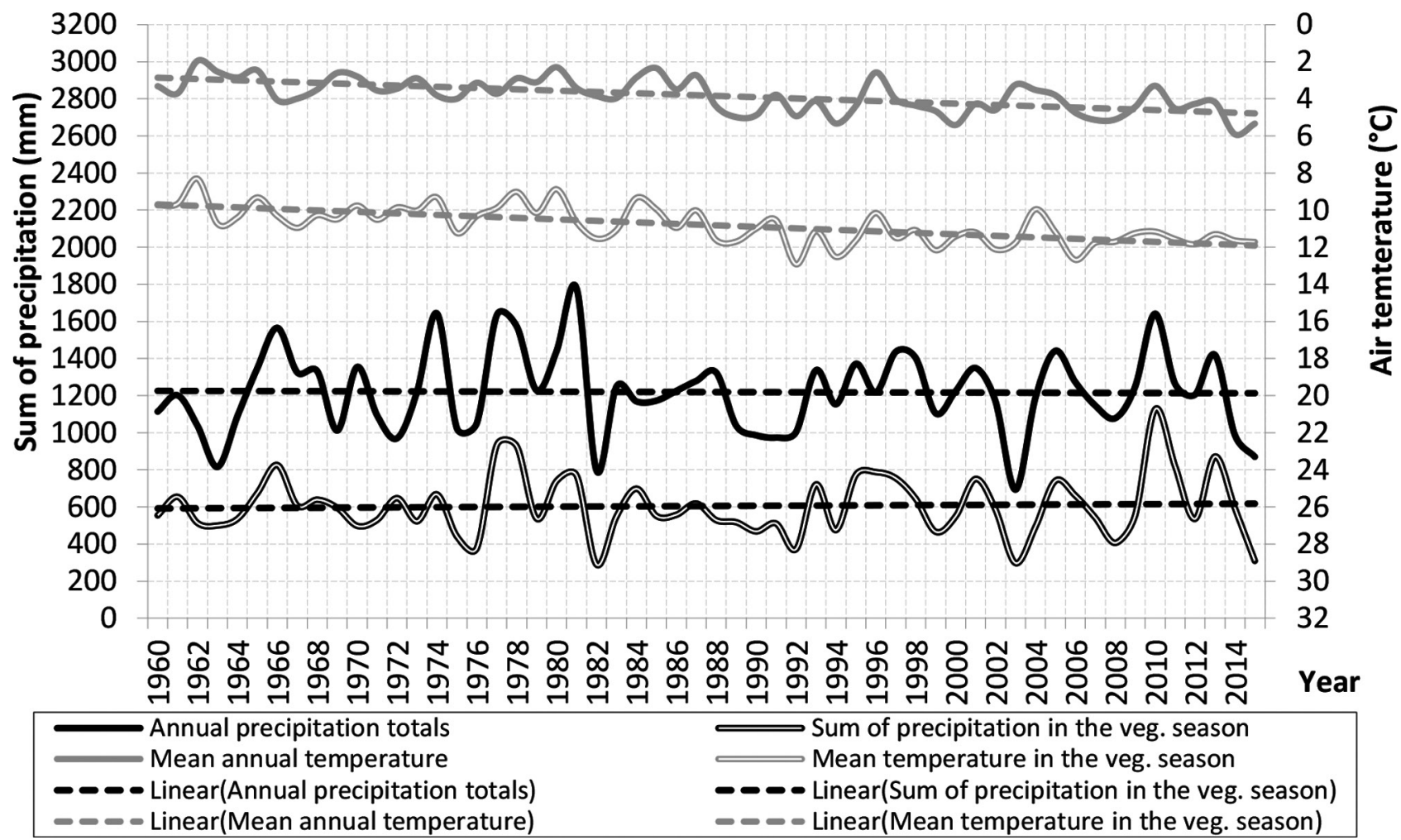

Fig. 2. The trend of average annual temperature, the growing season temperature $\left({ }^{\circ} \mathrm{C}\right)$, the total annual precipitation and the total precipitation amount $(\mathrm{mm})$ in the growing season at Bedřichov station in 1960-2015 

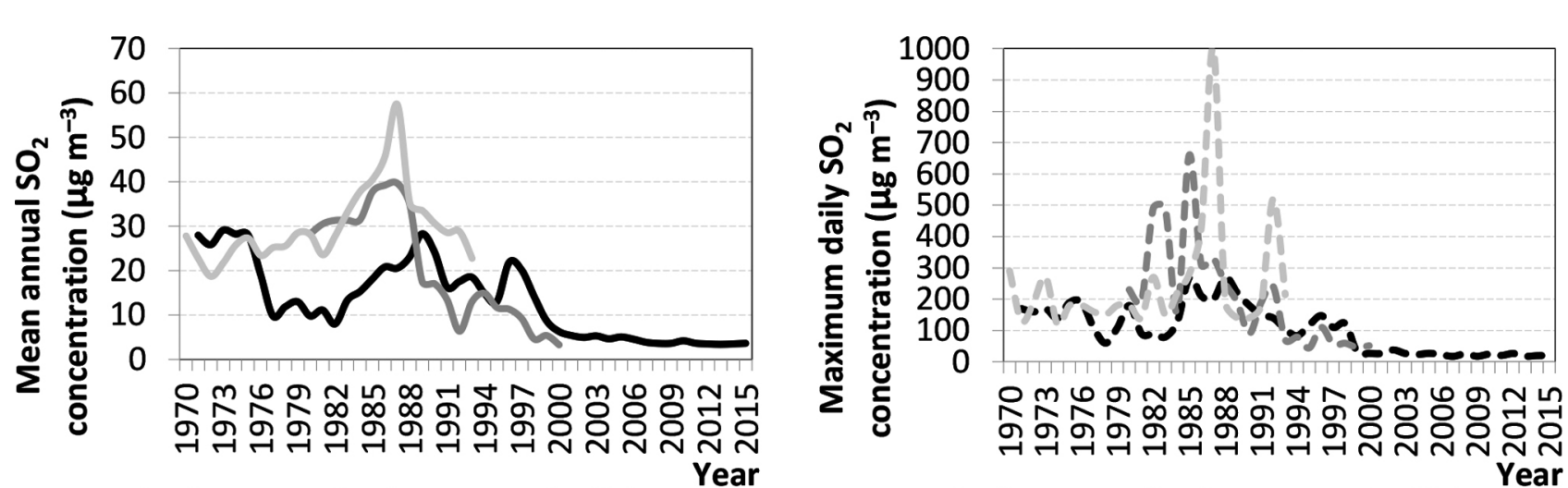

Souš Jizerka Bedřichov

- - - Souš

Bedřichov

Fig. 3. The average annual and maximum daily $\mathrm{SO}_{2}$ concentrations $\left(\mu \mathrm{g} \mathrm{m}^{-3}\right)$ at stations Souš, Bedřichov and Jizerka in 1970-2015
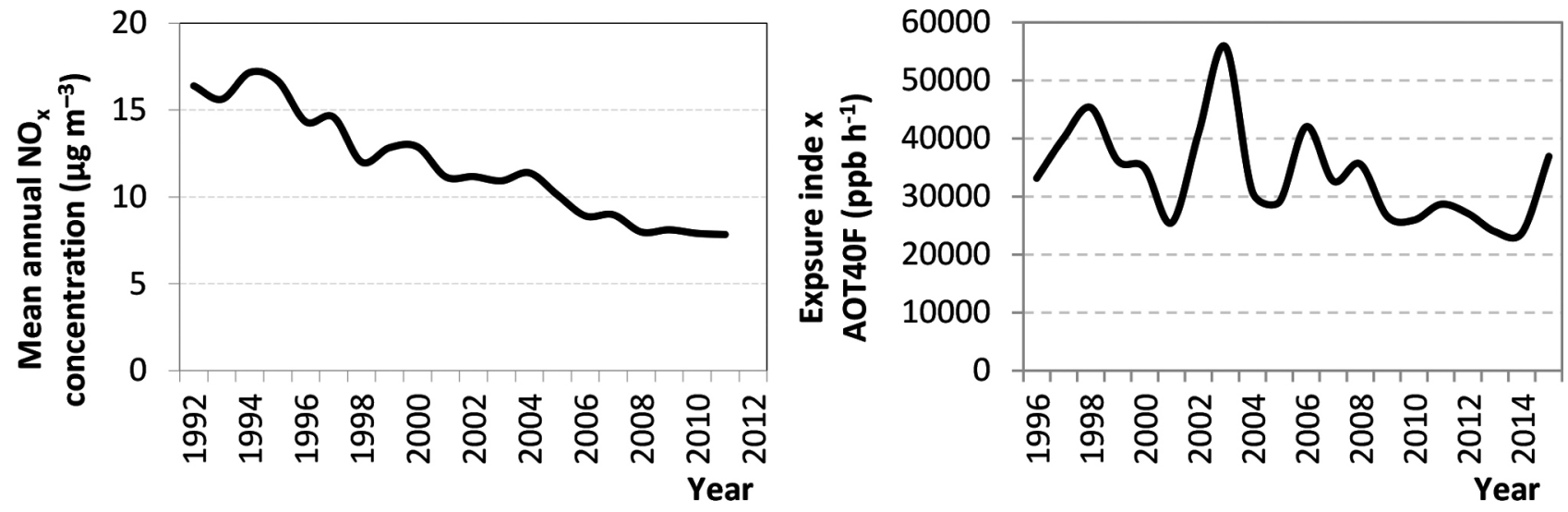

Fig. 4. The mean annual $\mathrm{NO}_{\mathrm{x}}$ concertation $\left(\mu \mathrm{g} \mathrm{m}^{-3}\right)$ in 1992-2012 and the ozone exposure index AOT40F for forests $\left(\mathrm{ppb} \mathrm{h}^{-1}\right)$ in 1996-2015 at the Souš station

\section{Dynamics of health status}

Average foliation and the percentage of defoliation degrees in a peaty spruce stand on PRP 1-4 in Norway spruce in 1980 document the stand condition in the first phase of the stand damage (average foliation of living trees and mortality on: PRP $153.3 \%$ and $4.9 \%$, PRP $252.3 \%$ and $6.3 \%$, PRP $351.2 \%$ and $6.9 \%$ and on PRP $452.7 \%$ and $3.6 \%$, in individuals with strongly suppressed growth on the deepest peat; Fig. 5). A pronounced decrease in foliation occurred in 1981-1983. This decrease was steep in 1981 (average annual defoliation of living trees and mortality on: PRP $110.6 \%$ and $26.8 \%$, PRP $211.6 \%$ and $20.7 \%$, PRP $314.5 \%$ and $26.3 \%$ and on PRP 4 $8.9 \%$ and $13.4 \%$, mostly in dominant and co-dominant trees). In 1982 this trend was more moderate (average annual defoliation of living trees and annual mortality on: PRP $12.9 \%$ and $22.6 \%$, PRP $21.6 \%$ and $18.3 \%$, on PRP $31.8 \%$ and $30.2 \%$ and on PRP $43.0 \%$ and annual mortality $22.9 \%$, also mostly in dominant and co-dominant trees). In 1983 there was a certain turnabout when the mortality process of the severely damaged trees continued (annual average mortality $18.1 \%$ ) but the foliation of living trees began to increase (ranged from $2.9 \%$ on PRP 4 to $5.7 \%$ on PRP 3).

In 1984, the health status was stabilized and there was a gradual moderate increase in the foliation of living trees until 2010 (average foliation of living trees $66.5 \%$ ). Foliation of living trees significantly increased in the course of time in this period $(p<0.001, r=0.89)$. After the division of the foliation trend for two time periods in terms of the air pollution load (before and after the year 1985), we witnessed significant higher mean foliation of living trees after year $1985\left(\mathrm{~F}_{1,46}=48.15, p<0.001\right)$. In 2015 the foliation of living trees significantly decreased $(p<0.01)$ compared to 2010 (on PRP 1 from $63.2 \%$ to $51.3 \%$, on PRP 2 from $65.8 \%$ to $44.7 \%$, on PRP 3 from $71.5 \%$ to $42.3 \%$ and on PRP 4 from $65.5 \%$ to $48.7 \%$ ). The mortality on all studied PRP was zero in 2015. The trend of spruce tree mortality on PRP 1-4 is illustrated in Fig. 6. 


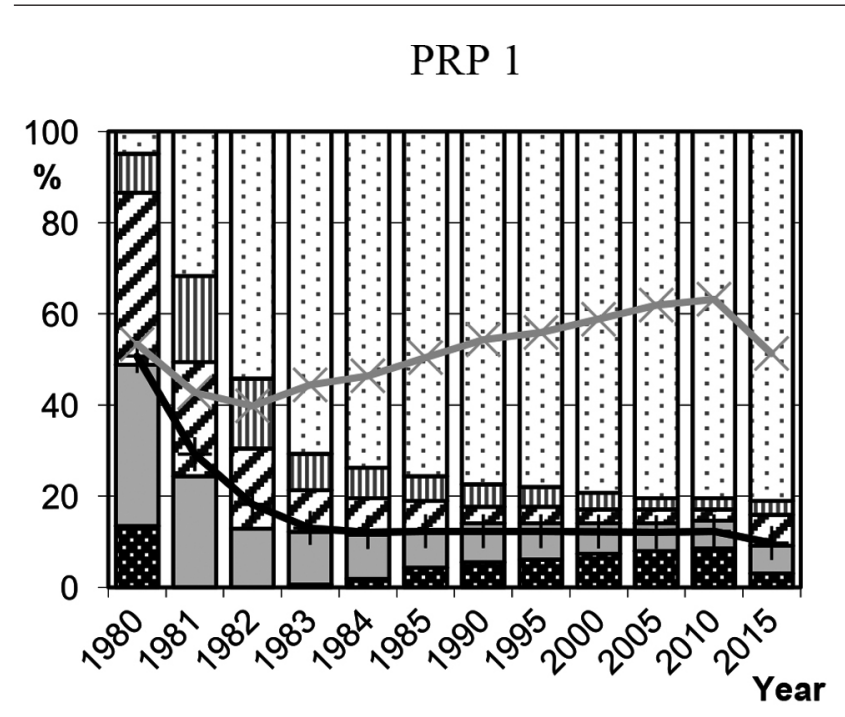

PRP 3

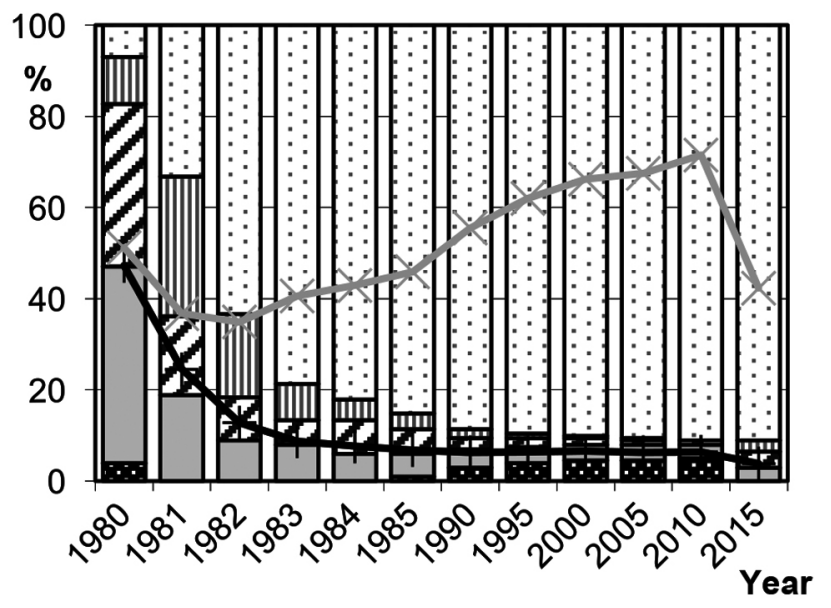

PRP 2

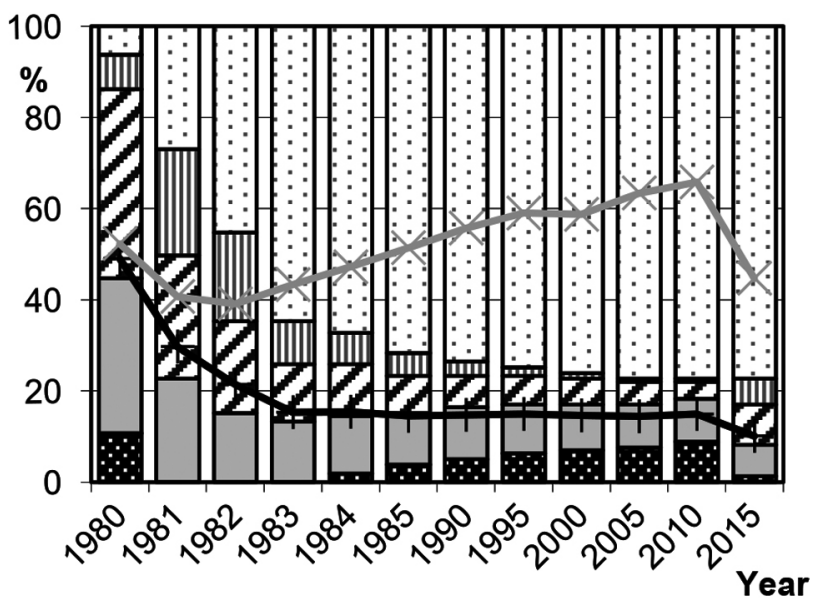

PRP 4

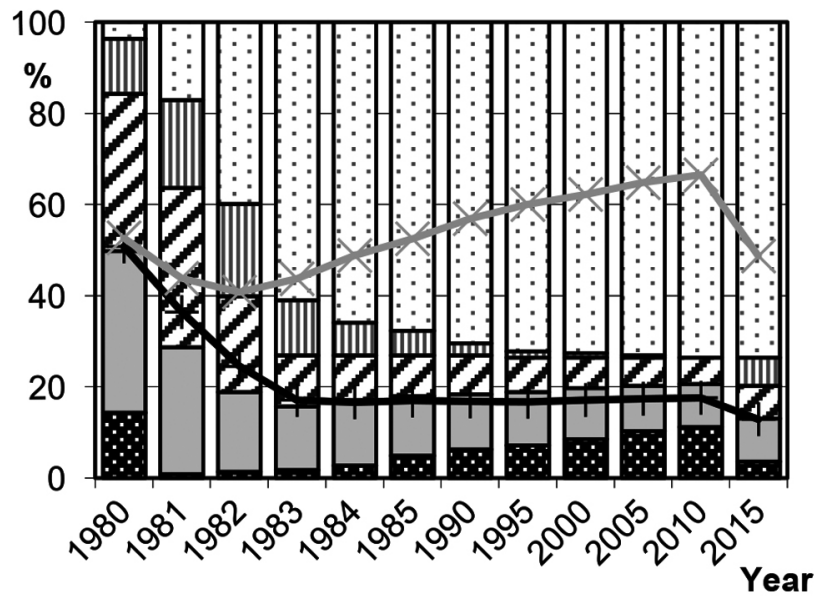

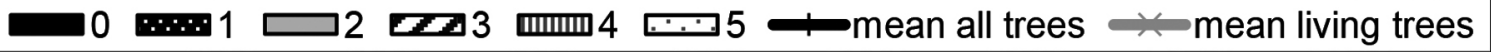

Fig. 5. The health status of peaty spruce stands according to foliation (\%) and five degrees of defoliation/needle loss on the permanent research plots 1-4 in 1980-2015; degrees of defoliation indicate: 0 - healthy trees (defoliation 0-10\%), 1 - slightly damaged trees (11-30\%), 2 - medium damaged (31-50\%), 3 - seriously damaged (51-70\%), 4 - dying trees $(71-99 \%), 5$ - dead trees $(100 \%)$

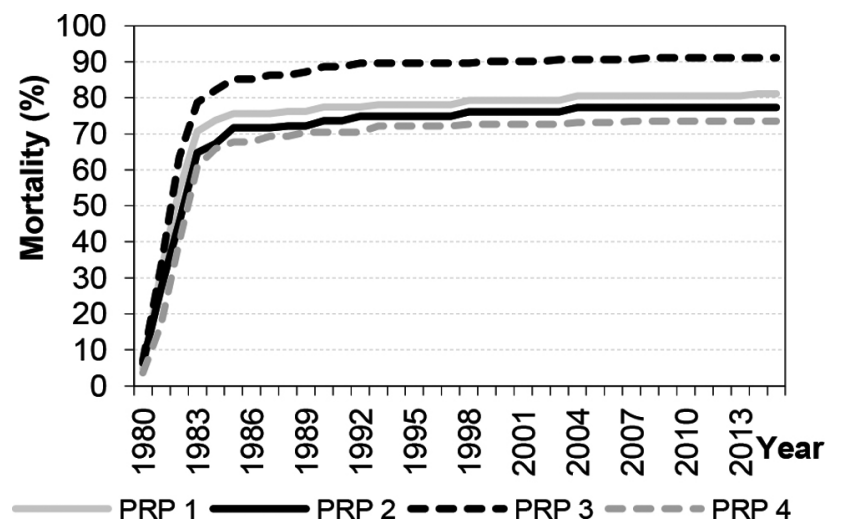

Fig. 6. Dynamics of mortality of spruce trees on the permanent research plots 1-4 in 1980-2015

\section{Nutrient concentrations in foliage}

The nutrient status of $\mathrm{N}, \mathrm{P}, \mathrm{K}, \mathrm{Ca}, \mathrm{Mg}, \mathrm{S}$ and $\mathrm{Si}$ was very unsatisfactory and unbalanced in the spruce stands (Fig. 7). The residues to $100 \%$ consisted mainly of the basic building materials of needles, namely carbon $(\mathrm{C})$, hydrogen $(\mathrm{H})$ and oxygen $(\mathrm{O})$, which were burnt from the dry matter as oxides within the carbon grid. Heavy metals ( $\mathrm{Al}$ - aluminium, Fe - iron, $\mathrm{Mn}$ - manganese, $\mathrm{Zn}$ - zinc, $\mathrm{Cu}$ - cuprum, $\mathrm{Pb}$ - lead, Cd - cadmium, Ni - nickel, $\mathrm{Cr}$ - chromium) were present in the foliage at least.

First of all, the nitrogen reserve was critical low. The values of nitrogen concentrations in the foliage 


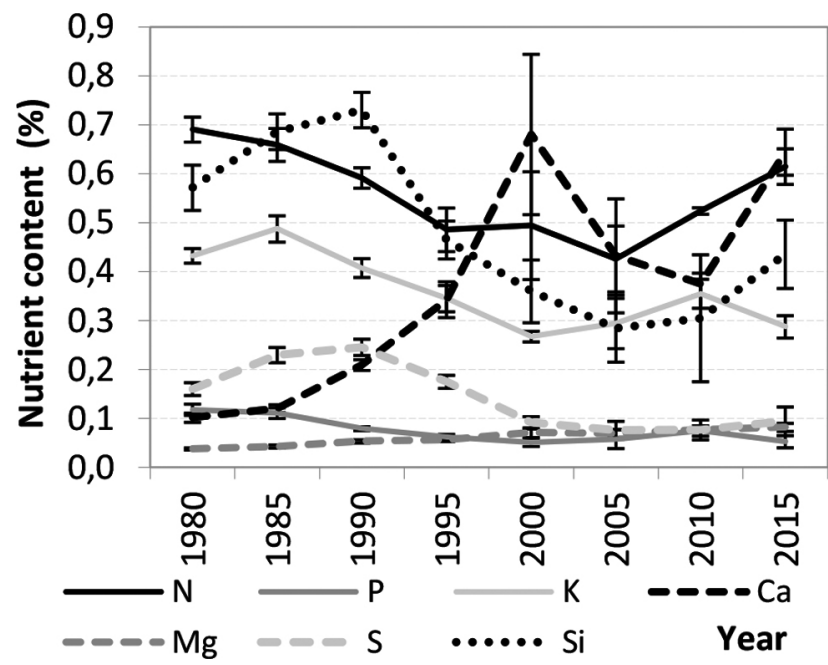

Fig. 7. Concentrations of nitrogen, phosphorus, potassium, calcium, magnesium, sulphur and silicon in dry matter of the foliage (needles) in 1980-2015; bars indicate standard deviation

of spruce were approximately at a half level of the limits defining deficiency (1.3\%), which corresponds to the extreme type of site. They decreased from the initial values around $0.7 \%$ in 1980 to the values oscillating around $0.5 \%$ in 2010 , with the minimum values in 2005. In the last period they increased again to about $0.6 \%$.

In the same period, the content of foliar phosphorus decreased from $0.10-0.13 \%$ in 1980 to $0.3-0.7 \%$ in 2015, which indicates a generally worse reserve of this nutrient in the relevant sites in the period of observations. The concentrations mostly indicated a deficiency while in 1980 they reached the limit of sufficient nutrition (UNECE, 2005). The potassium content also dropped considerably when minimum values were found around the year of 2000, and have remained unchanged until now. The content of this nutrient in foliar tissues was at the lower limit of sufficient nutrition while in 2000 and 2015 it reached the limit of deficiency. On the contrary, the content of foliar calcium increased from deficiency values in 1980 to the values indicating an optimum reserve of this nutrient, and the same applies to the magnesium content in the needles of studied spruce trees. The content of foliar sulphur gradually increased at first, from 1980 to 1990 it reached the double of the values considered as the limit of negative effects $(0.12 \%)$.
Then a dramatic drop was documented until 2000 to the values considered as deficiency. Anthropogenic effects on the nutrient status of forest stands in the studied area are very noticeable.

Comparing the first and the second half of the investigated period, there were significant differences in the nutrient content of all elements $(p<0.001$; Fig. 7). In 2000-2015 the nutrient content was significantly lower on all PRP in nitrogen $\left(\mathrm{F}_{1,30}=7.7\right)$, phosphorus $\left(\mathrm{F}_{1,30}=19.8\right)$, potassium $\left(\mathrm{F}_{1,30}=39.2\right)$, sulphur $\left(\mathrm{F}_{1,30}=104.0\right)$ and silicon $\left(\mathrm{F}_{1,30}=45.8\right)$ and significantly higher in calcium $\left(\mathrm{F}_{1,30}=45.9\right)$ and magnesium $\left(\mathrm{F}_{1,30}=72.9\right)$ than in 1980-1995. The development over the time (1980-2015) had a significant effect on nutrient concentrations in the foliage $(p<0.001)$. Time was significantly $(p<0.001)$ negatively correlated with the content of nitrogen $(\mathrm{r}=-0.45)$, phosphorus $(\mathrm{r}=-0.73)$, potassium $(r=-0.73)$, sulphur $(r=-0.74)$ and silicon $(\mathrm{r}=-0.68)$ and positively with calcium $(\mathrm{r}=0.75)$ and magnesium $(r=0.91)$. In terms of the content, the greatest changes occurred in magnesium, sulphur and calcium during the time.

\section{Radial growth}

The characteristics of dendrochronology analysis of spruce trees (24-29 sample cores) are numerically described in Table 2 that shows the basic indicators. The age of the tree core samples ranged from 83245 years (mean 147 years). The average tree-ring width of spruce was the lowest on PRP $3(0.776 \mathrm{~mm}$ $\pm 0.256 \mathrm{SD})$ and PRP $2(0.807 \mathrm{~mm} \pm 0.297 \mathrm{SD})$, while the highest increment was on PRP 4 (1.226 $\mathrm{mm} \pm 0.437 \mathrm{SD})$ and PRP $1(1.037 \mathrm{~mm} \pm 0.309$ $\mathrm{SD})$. The expression population signal shows a significant value (significant EPS level is 0.850 ) on all PRP (0.859-0.934).

The results of tree ring analyses from PRP 1-4 document following negative pointer years with extremely low radial growth: 1980, 1981, 1982, 1983, 1984, 1985, 1990, 1996, 2010 and 2015 on particular PRP (Table 2, Fig. 8). The highest number of negative years were on PRP 3 and 4 (7 years), while on PRP 1, only 3 negative years were observed. Years 1981 and 1982 were common negative pointer years in all PRP. Very strong growth depression was observed in 1979-1987 caused by the synergism of air

Table 2. Characteristic of the tree-ring chronologies and significant negative pointer years characterizing extreme low radial growth on the permanent research plots 1-4 in 1960-2015

\begin{tabular}{cccccccc}
\hline ID & $\begin{array}{c}\text { No. of } \\
\text { samples }\end{array}$ & Mean (mm) & Min (mm) & Max $(\mathrm{mm})$ & $\begin{array}{c}\text { Standard } \\
\text { deviation }\end{array}$ & $\begin{array}{c}\text { Expression popul. } \\
\text { signal }\end{array}$ & Negative pointer years \\
\hline 1 & 29 & 1.037 & 0.535 & 1.810 & 0.309 & 0.926 & $1980,1981,1982$ \\
2 & 29 & 0.807 & 0.364 & 1.576 & 0.297 & 0.934 & $1981,1982,1984,1985$ \\
3 & 24 & 0.776 & 0.276 & 1.133 & 0.256 & 0.859 & $1981,1982,1983,1984,1990,2010,2011$ \\
4 & 27 & 1.226 & 0.365 & 2.082 & 0.437 & 0.889 & $1980,1981,1982,1983,1984,1996,2015$ \\
\hline
\end{tabular}




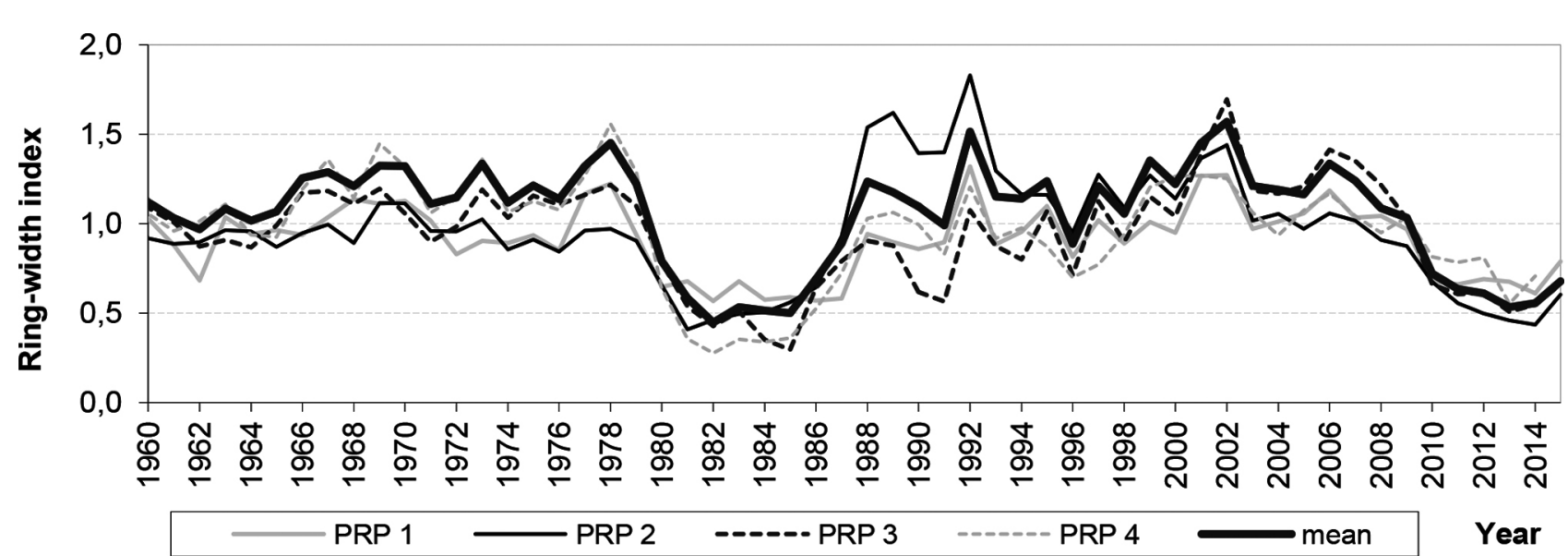

Fig. 8. The ring-width chronology of Norway spruce from the particular permanent research plots 1-4 in 1960-2015 (displayed for common interval)

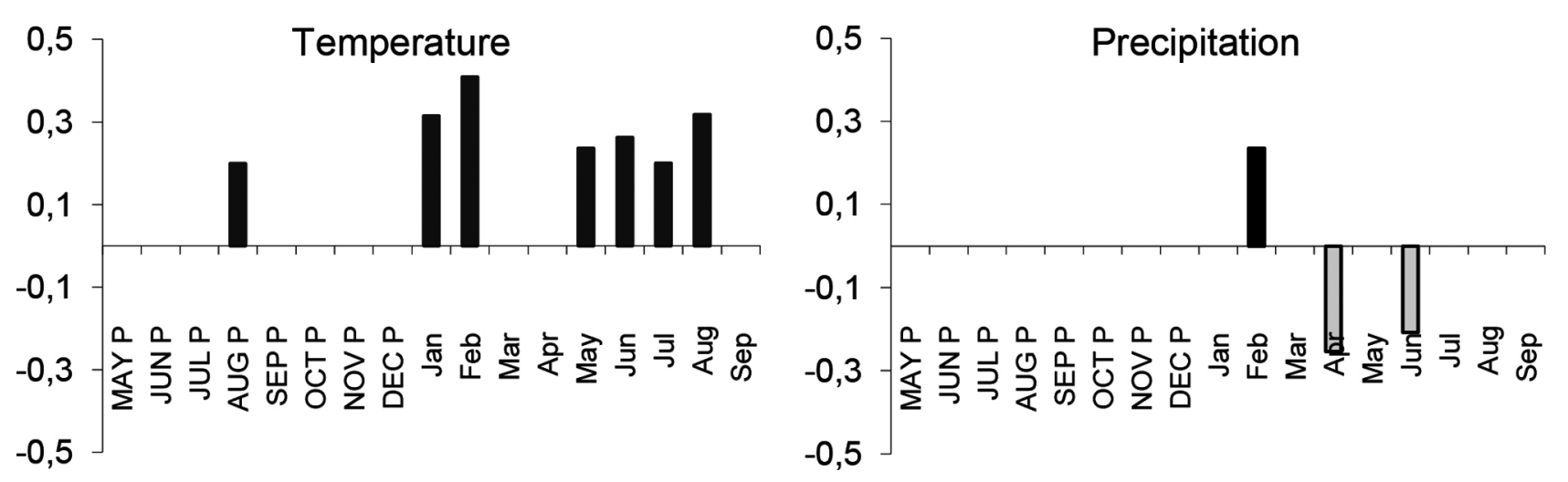

Fig. 9. Correlation coefficients of the regional residual index tree-ring chronology with the monthly temperature (left) and the total precipitation (right) from May to December of the previous year (capital letters) and from January to September of the given year (small letters) on PRP 1-4 in total in 1960-2015; only correlation coefficients of statistically significant values $(\alpha=0.05 \%)$ are represented
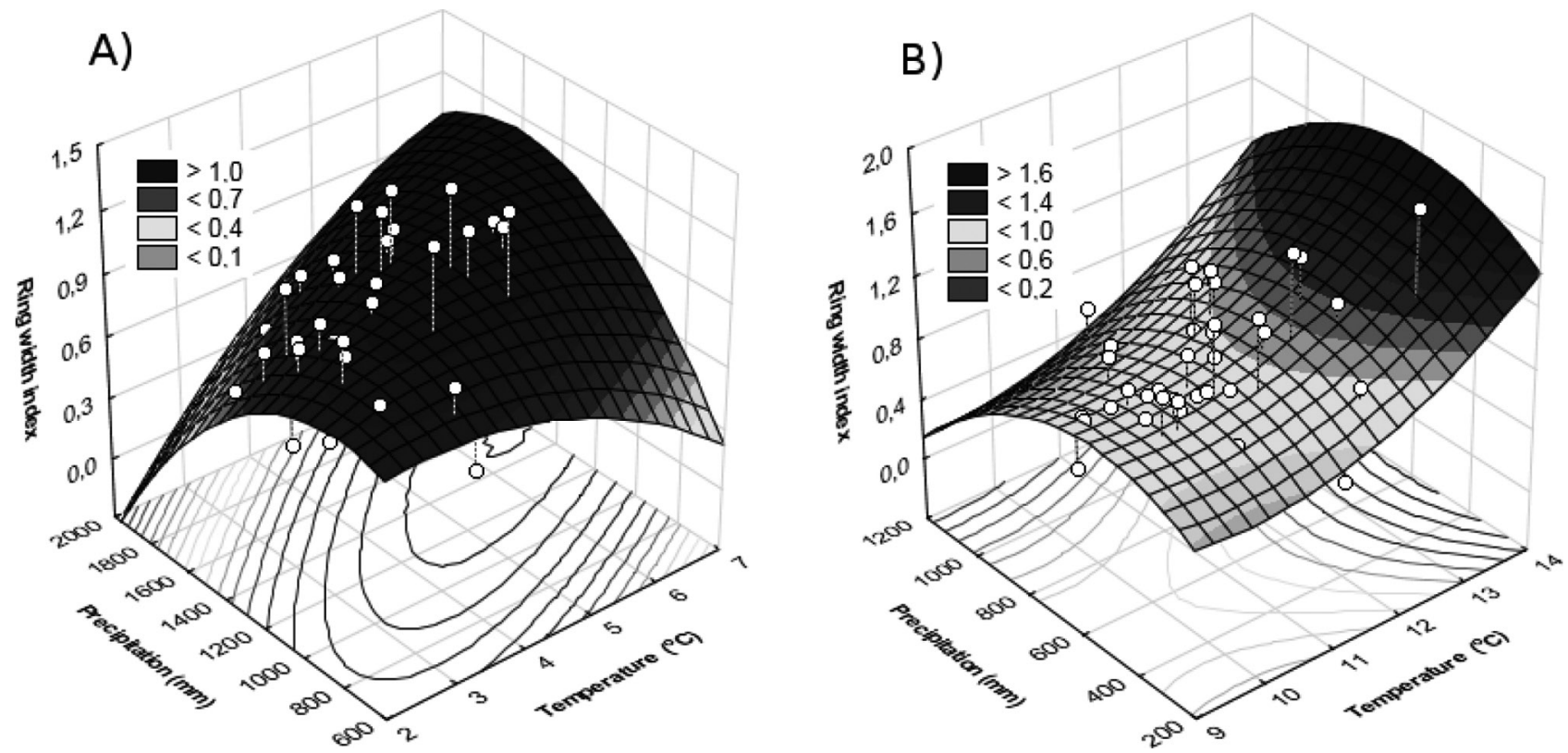

Fig. 10. Response of the ring width index of Norway spruce to the sum of precipitation and the mean temperature in the current year A) and in the growing season B) (correlation quadratic model, years 1960-2015) 
pollution (extremely high $\mathrm{SO}_{2}$ concentration) and climatic extremes. The year of 1980 was the second coldest year in the observed period of 1960-2015 $\left(2.3{ }^{\circ} \mathrm{C}\right.$, the mean $\left.3.8^{\circ} \mathrm{C}\right)$ related to late frosts. Consequently, the highest annual amount of precipitation was observed in $1981(1,778 \mathrm{~mm}$, the mean $1,219 \mathrm{~mm})$, while the second driest year $(795 \mathrm{~mm}$, the mean 1,219 $\mathrm{mm}$ ) was 1982 related, again, to late frosts. Extremely cold and dry winter were typical for the years 1985 and 1996, while the negative year 1990 was, by contrast, an extremely hot year. There was also an evident growth depression in 2009-2015 resulting mainly from the climate extremes. In the negative pointer year 2010, the second highest annual amount of precipitation was observed $(1,642 \mathrm{~mm}$, the mean $1,219 \mathrm{~mm}$ ). Moreover, in that year, the new needles became frostbitten due to late frosts and the growth was thus reduced. The year 2015 was characterized by the driest $(99 \mathrm{~mm}$, the mean $282 \mathrm{~mm}$ ) and extremely warm $\left(15.5^{\circ} \mathrm{C}, 12.7^{\circ} \mathrm{C}\right)$ June and July, when the major part of radial growth is formed.

After the division of the ring-width curves for three seasons in terms of air pollution load (before 1960-1979, during 1979-1988 and after the $\mathrm{SO}_{2}$ load 1988-2015), there were significant differences between these periods $\left(\mathrm{F}_{2,221}=61.41 ; p<0.001\right)$. In the period of 1979-1988, trees had significantly lower increment (the mean ring index 0.55) than in the other two periods $(p<0.001)$. Comparing radial growth between periods before (1.04) and after (0.99) the $\mathrm{SO}_{2}$ load, there were no significant differences in the tree ring index $(p>0.05)$.

The mean diameter increments in 1960-2015 correlated positively with the temperature in August of the preceding year $(r=0.20)$ and positively with the temperature in January, February, May, June, July and August of the current year $(\mathrm{r}=0.32,0.41,0.24$, $0.26,0.20$ and 0.32 , respectively). Besides, the radial growth was in positive correlation with the precipitation in February $(r=0.24)$, in negative correlation with the precipitation in April and May of the current year $(r=-0.26$ and -0.22 , resp.; Fig. 9). The temperature was identified as a factor positively influencing the diameter increment of spruce in the study area (Fig. 10). The diameter increment considerably increased with increasing temperature, especially in the growing season. On the other hand, the optimal range of precipitation for the radial growth was from 550 to $600 \mathrm{~mm}$ in the growing season.

\section{Relations between air pollution, climate and radial growth}

The radial growth increment showed a significantly negative correlation with the mean annual and maximum daily $\mathrm{SO}_{2}$ concentrations (Table 3 ), especially on PRP $4(\mathrm{r}=-0.55)$ and PRP $1(\mathrm{r}=-0.49$; no influence on PRP 3, $r=0.03$ ), positive correlation with the foliation of living trees, mean annual $\mathrm{NO}_{\mathrm{x}}$ concentrations, average temperature outside the growing season and in January-March of the current year and no correlation with precipitation. The foliation of living trees was negatively correlated with $\mathrm{SO}_{2}$ concentrations and maximum daily $\mathrm{NO}_{\mathrm{x}}$ concentrations, positively with radial growth increment and there was no correlation with any climatic factors. The annual mortality showed a significantly positive correlation with $\mathrm{SO}_{2}$ concentrations and amount of precipitation outside the growing season of the current year and negative correlation with the foliation of living trees, radial growth and temperature in the growing season of the previous year (Table 3 ). No significant effect of the ozone exposure index AOT40F was observed on the studied spruce stands.

The results of the PCA analysis are presented in the ordination diagram in Fig. 11. The first ordination axis explains $32.4 \%$ of the variability in the data, the first two axes together explain $54.0 \%$, and the first four axes together explain $78.8 \%$. The first $\mathrm{x}$-axis represents the annual radial increment together with temperatures in both the current and the

Table 3. Correlations between the radial growth increment (1960-2015) and health status (1980-2015) and climate (1960-2015) and air pollution factors $\left(\mathrm{SO}_{2}\right.$ 1970-2015, NO $\mathrm{N}_{\mathrm{x}}$ 1992-2012, AOT40F 1996-2015)

\begin{tabular}{|c|c|c|c|c|c|c|c|c|c|c|}
\hline & $\begin{array}{c}\mathrm{SO}_{2} \\
\text { Mean }\end{array}$ & $\begin{array}{l}\mathrm{SO}_{2} \\
\mathrm{Max} \\
\end{array}$ & $\begin{array}{c}\mathrm{NO}_{\mathrm{x}} \\
\text { Mean }\end{array}$ & $\begin{array}{l}\mathrm{NO}_{x} \\
\mathrm{Max}\end{array}$ & AOT40F & $\begin{array}{c}\text { Tem } \\
\text { ActAnn }\end{array}$ & $\begin{array}{c}\text { Tem } \\
\text { ActVeg }\end{array}$ & $\begin{array}{c}\text { Tem } \\
\text { LasVeg }\end{array}$ & $\begin{array}{c}\text { Tem } \\
\text { ActNon }\end{array}$ & $\begin{array}{c}\text { Tem } \\
\text { ActI-III. }\end{array}$ \\
\hline AnRing & $-0.44^{* *}$ & $-0.48^{* *}$ & $0.53^{*}$ & 0.16 & 0.30 & $0.39^{* *}$ & 0.28 & 0.16 & $0.42^{* *}$ & $0.50^{* *}$ \\
\hline Foliation & $-0.62^{*}$ & $-0.73^{* *}$ & -0.81 & $-0.92 *$ & -0.83 & 0.16 & 0.16 & 0.32 & 0.30 & 0.08 \\
\hline \multirow[t]{2}{*}{ Mortality } & $0.49 * *$ & $0.56^{* *}$ & 0.26 & -0.03 & 0.23 & -0.24 & -0.18 & $-0.36^{*}$ & -0.22 & -0.09 \\
\hline & $\begin{array}{c}\text { Tem } \\
\text { ActVI-VII. }\end{array}$ & $\begin{array}{c}\text { Pre } \\
\text { ActAnn }\end{array}$ & $\begin{array}{c}\text { Pre } \\
\text { ActVeg }\end{array}$ & $\begin{array}{c}\text { Pre } \\
\text { LastVeg }\end{array}$ & $\begin{array}{c}\text { Pre } \\
\text { ActNon }\end{array}$ & $\begin{array}{c}\text { Pre } \\
\text { ActI-III. }\end{array}$ & $\begin{array}{c}\text { Pre } \\
\text { ActVI-VII. }\end{array}$ & WatBal & AnRing & Foliation \\
\hline AnRing & 0.19 & -0.02 & -0.11 & -0.12 & -0.01 & 0.06 & -0.13 & -0.17 & $1.00 * *$ & $0.63^{*}$ \\
\hline Foliation & 0.25 & 0.35 & 0.57 & -0.39 & -0.01 & 0.20 & 0.07 & 0.46 & $0.63^{*}$ & $1.00 * *$ \\
\hline Mortality & -0.13 & 0.09 & -0.11 & 0.00 & $0.40^{*}$ & 0.16 & -0.00 & -0.02 & $-0.62 *$ & $-0.79 * *$ \\
\hline
\end{tabular}

Notes: AnRing - annual ring width, Foliation - foliation of living trees, Mortality - Annual mortality, $\mathrm{SO}_{2}$ and $\mathrm{NO}_{\mathrm{x}}$ concentrations (mean - mean annual concentration, max - maximum daily concentration), AOT40F - ozone exposure index, Tem - mean temperature, Pre - sum of precipitation, Ann - annual, Act - current year, Las - last year, Veg - vegetation season, Non - non vegetation season, WaterBal - water balance, I-III and VI-VII - months; significant correlations are indicated with an asterisk $(* p<0.05, * * p<0.01)$. 


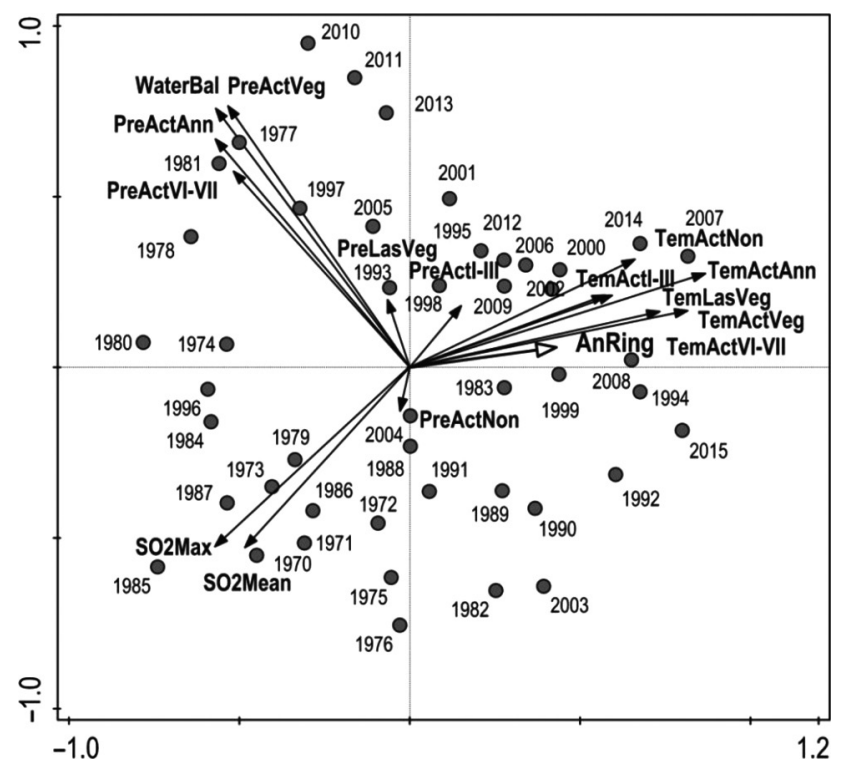

Fig. 11. Ordination diagram showing results of the PCA analysis of relationships between climate data (Tem average temperature, Pre - amount of precipitation, Act - current year, Las - last year, Veg - growing season, WaterBal - water balance; I-III, VI-VII - months), $\mathrm{SO}_{2}$ concentrations (mean - mean annual concentration, max - maximum daily concentration) and the ring width (AnRing - annual ring width); codes of filled circles indicate the years 1970-2015

previous years. The second y-axis represents precipitation parameters. The annual ring increment of trees was negatively correlated with the maximum daily and mean annual $\mathrm{SO}_{2}$ concentrations. Average temperatures had a positive effect on the tree ring increment, especially temperatures in June-July and temperatures in the growing season of the current year, while the radial growth was not correlated, or was correlated only very slightly, with any precipitation parameter. Precipitation in the growing season of the last year, precipitation in January-March and precipitation outside the growing season of the current year were the weakest explanatory variables in the diagram. On the contrary, the water balance and precipitation in the growing season of the previous year had the highest loading in the diagram. In terms of time, the radial growth of trees during the first half of the investigated period (1980s, 1990s) was related more closely to $\mathrm{SO}_{2}$ concentrations and precipitation parameters, whereas during the second half of the investigated period (after 2000) it was related more closely to the temperature.

\section{Discussion}

Pronounced air-pollution stress that afflicted the Jizerské hory Mts. in the 1970s and 1980s caused severe deterioration of the health status of peaty spruce stands as a consequence of the synergism of air pollution, climate extremes and insect outbreaks, similarly to other Sudetes mountains (Král et al., 2015; Vacek et al., 2015). In these studies, it was identically stated that heavy destruction of these forests started in 1981 as a result of the synergism of very strong winter desiccation in early spring and high $\mathrm{SO}_{2}$ concentrations. A similar increase in defoliation to forest stands was documented in mountains climax spruce stands by many studies (Vacek \& Matějka, 2010; Vacek et al., 2013). Similar findings were reported from the Orlické hory Mts. (Žid \& Čermák, 2008) with the most damaged stands in the summit parts. A study from the Polish mountain range documented that damage to spruce stands was caused by air pollution that impairs the nutrient balance in soil (Mazurski, 1986). Schulze et al. (1989) had almost an identical opinion on the cause of damage to spruce stands in Central Europe, and ascribed great acidification in these stands to the capacity of spruce to intercept a high amount of air pollutants. Despite the general decrease in acid deposition (Hůnová et al., 2014) the regeneration of forest soils has not been sufficient (Borůvka et al., 2005), defoliation is still great (Fabiánek et al., 2012) and many symptoms of damage to the foliage are connected with nutrition disorders as reported from the Jizerské hory Mts. (Lomský et al., 2012). A similar statement was confirmed in our study, when the soil regeneration is still insufficient, especially on PRP 3 and 4, where the water regime close to PRP was modified (by drainage, building roads, dams) in the past and thus the peat profile mineralization was accelerated. Moreover, defoliation has decreased in comparison to the 1980s, but it is still higher than it had been in the period before the air pollution load. Also, nutritional disorders are sometimes seen on the foliage as increased yellowing symptoms.

The health status was threatened to the largest extent in the 1980s, which corresponds with the air pollution culmination in Central Europe (Zimmermann et al., 2002; Lomský et al., 2012). The air quality started improving after 1990 (Hůnová et al., 2004). An improvement in the trend of air pollution in terms of the concentrations of $\mathrm{SO}_{2}$ and $\mathrm{NO}_{\mathrm{X}}$ is also documented by our study since 1994. Gradual improvement in health status between 1998 and 2004 was confirmed from the neighbouring Krkonoše Mts. by Staszewski et al. (2012). However, the health status of forest stands after 2010 started to worsen again, probably due to diminished water availability and by more frequent events of climate extremes (drought, high temperatures). Decreased availability of water as a limiting factor that usually manifests itself primarily in the lowlands (Tumajer \& Treml, 2017), can be - surprisingly - a limiting factor even at high altitudes (Etzold et al., 2014). In connection 
with diminished water availability and more frequent and longer drought spells, high defoliation and the risk of bark beetle attacks to spruce stands increases (Krejčí et al., 2013; Šrámek et al., 2015).

Ozone air pollution is a significant stress factor in the Jizerské hory Mts. in the summer season as its concentrations exceed - in the long run - the threshold values for vegetation protection $\left(9,000 \mathrm{ppb} \mathrm{h}^{-1}-\right.$ limit of vegetation damage) according to the Czech Air Protection Act. The limit values are exceeded throughout a major part of the growing season. $\mathrm{O}_{3}$ concentrations were quite high in the studied years, especially in 1997, 1998, 2002, 2003 and 2006, when the AOT40F index exceeded 40,000 $\mathrm{ppb} \mathrm{h}^{-1}$. Similar findings from the Sudetes mountain range were reported by Šrámek et al. (2007) and Vacek et al. (2015).

The results of leaf analyses also document the impacts of air pollutants and other factors on the nutrient status of forest stands in the studied region. In the first period a decrease or a low level of bases were revealed, given by either natural or anthropogenic acidification of the environment (Hůnová et al., 2014). A decrease in nitrogen and phosphorus was also found. Approximately since 1990 there has been a fast increase in calcium and a moderate increase in magnesium, which indicates the influence of liming in the region as in other mountain ranges (Šrámek et al., 2006). An increase in nitrogen content since 2005 can be ascribed to high deposition of this element which is not, however, able to prevent its critical deficiency with regard to the nutrition of forest stands. Our assessment of the nutrient status of peaty spruce forests of the Jizerské hory Mts. using the ICP Forests methodology (UNECE, 2005) was very similar to the results of Bergmann (1988) and Ulbrichová and Šimková (2007). Very low values of the nitrogen content were demonstrated in Šumava peat bogs by Materna (1960) although the values he determined were somewhat higher even in stunted spruce trees. On the contrary, the sulphur and silicon content measured in his study was much lower.

The standardized tree-ring chronology in the Jizerské hory Mts. indicates a gradual decrease in radial increment in 1979-1987, similarly to other mountain spruce stands in the Czech Republic (Kroupová, 2002; Král et al., 2015; Vacek et al., 2015). According to the cited authors the cause of the increment decrease was a strong air pollution load, especially of $\mathrm{SO}_{2}$ emissions in the 1970s and 1980s, in combination with climate factors. Since the second half of the 1990s a gradual increase in growth has been recorded. That period was characterized by mild winters without pronounced temperature extremes, by relatively high temperatures in the growing season and by a decrease in air pollution but high $\mathrm{NO}_{\mathrm{x}}$ depositions (Vejpustková et al., 2004). A distinct increase in radial increment in this period was documented in the Orlické hory Mts. (Rybníček et al., 2009; Králíček et al., 2017), in the Krkonoše Mts. (Král et al., 2015; Putalová et al., 2019), Broumovsko (Vacek et al., 2019c) and in the Polish Beskids (Feliksis, 1995; Wilczyński \& Feliksik, 2005). A strong decrease in radial growth started in 1979 as a consequence of temperature shock at the turn of 1978-1979, when the temperature dropped by almost $30^{\circ} \mathrm{C}$ within 24 hours (Vacek et al., 2015). In 1980-1986 it was due to the synergism of air pollution and climatic stress, and in 1996 and 2010 it was a result of winter desiccation of the foliage in early spring. Several negative pointer years (1979 and 1981) were also identical in peaty spruce stands in the summit parts of Orlické hory Mts. (Rybníček et al., 2009; Vacek et al., 2015).

An interpretation of correlations of radial increment with climatic factors is rather complicated because the growth process is influenced by many factors (Dorotovič et al., 2014; Remeš et al., 2015; Vacek et al., 2016, 2017; Šimůnek et al., 2019; Cukor et al., 2020). The positive effect of temperatures in the growing season on radial increment can be explained by conditions in a period when a considerable part of radial increment is created. Hence temperatures do not limit growth if the water reserve in soil is sufficient. Similar results showing the positive effect of temperature in July and August on spruce growth were also found in spruce forests in the western Carpathians (Bednarz et al., 1999), in the Krkonoše Mts. (Král et al., 2015), in Orlické hory Mts. (Rybníček et al., 2009; Vacek et al., 2015) and in the Polish Tatras (Feliksik, 1972). The relations between precipitation and temperatures in the growing season were described in a similar way in Germany (Dittmar \& Elling, 2004), Switzerland (Meyer \& Bräker, 2001) and Poland (Koprowski \& Zielski, 2006). In addition, a negative effect of precipitation on growth in April and June of the current year was, similarly to our study, reported from peaty spruce stands in the Krkonoše Mts. (Král et al., 2015).

Generally, from 1960 to 2015 the average annual amount of precipitation in the studied localities decreased minimally (by $14 \mathrm{~mm}$ on average), while a marked rise in the average annual temperature (by $1.9{ }^{\circ} \mathrm{C}$ ) was observed. Climate changes and air pollution are mutually integrating influences that affect forest ecosystems, the species composition and species distribution, soil environment, health status, water availability and tree growth (Bytnerowicz et al., 2007), which is quite clearly apparent from the results of our study. Climate changes and particularly high temperatures have distinct consequences for the whole ecosystem. The influence of climate changes on growth in relation to the increment of forest stands is generally positive in our study but on condition that water is not a strongly limiting factor. This finding is in line with the results of Laubhann et 
al. (2009) where the authors observed a significant influence of climate warming on 152 spruce stands throughout Europe. Researches (Solberg et al., 2009; Schuster \& Oberhuber, 2013) confirmed a positive effect of temperature increase on radial growth of spruce if the growth was not limited by water deficien$\mathrm{cy}$, especially in growing season. A more pronounced reduction in radial growth in relation to diminished water availability is more clearly manifested in older trees (Pichler \& Oberhuber, 2007) because ecophysiological studies showed that changes in the tree size are related to the changes in physiological processes taking place in trees during their aging (Mencuccini et al., 2005). This fact is compounded by the age of trees in the study stands reaching up to 250 years.

\section{Conclusion}

The analysis of air pollution and climate factors in the summit parts of the Jizerské hory Mts. shows the occurrence of predisposing factors that have a potential, through their synergic effects, to cause gradual decline of spruce forests. Until 1978 there was close interaction between the occurrence of negative years and climate extremes when forest stands reacted in accordance with the specific site and stand conditions. Pronounced deterioration of the health status of spruce stands as a consequence of the synergism of air pollution, especially high $\mathrm{SO}_{2}$ concentrations, and climatic stress occurred in 1979-1988. It was documented not only by strong defoliation but also by a decrease in radial increment. In addition, winter desiccation, low temperatures and high precipitation were the limiting factors for radial growth in the studied peat mountain area. From the second half of the 1980s until 2000 the health status of spruce stands was relatively stabilized, considering the foliation trend of living trees and their radial increment. Since 2010 there has been a significant defoliation comparable to the defoliation trend in 1980-1983, only with low mortality so far. This trend is also reflected by a significant decline in radial growth in 2010-2015. It is a question of how the health status of these spruce stands will develop during ongoing global climatic changes, whereas the foliation of most spruce in the tree layer on the PRP is approaching the limit of critical foliation.

\section{Acknowledgement}

This study was supported by the Czech University of Life Sciences Prague, Faculty of Forestry and Wood Sciences. We are grateful to three anonymous reviewers and editor-in-chief for their constructive comments and valuable suggestions that helped improve the manuscript.

\section{References}

Alewell C \& Bebi P (2011) Forest development in the European Alps and potential consequences on hydrological regime: Forest management and the water cycle: An ecosystem-based approach (ed. by M Bredemeier, S Cohen, DL Godbold, E Lode, V Pichler \& P Schleppi) Springer, Berlin.

Bednarz Z, Jaroszewicz B, Ptak J \& Szwagrzyk J (1999) Dendrochronology of the Norway spruce (Picea abies (L.) Karst.) from the Babia Gora National Park, Poland. Dendrochronologia 16: 45-55.

Bergh J, Linder S \& Bergström J (2005) Potential production of Norway spruce in Sweden. Forest Ecology and Management 204: 1-10.

Bergmann W (1988) Ernährungsstörungen bei Kulturpflanzen. G. Fischer Verlag, Jena.

Biondi F \& Waikul K (2004) Dendroclim2002: $\mathrm{AC}++$ program for statistical calibration of climate signals in tree-ring chronologie. Computers \& Geosciences 30: 303-311.

Błaś M, Sobik M \& Twarowski R (2008) Changes of cloud water chemical composition in the Western Sudety Mountains, Poland. Atmospheric Research 87: 224-231.

Bonan GB (2008) Forests and climate change: forcings, feedbacks, and the climate benefits of forests. Science 320: 1444-1449.

Borůvka L, Podrázský V, Mládková L, Kuneš I \& Drábek O (2005) Some approaches to the research of forest soils affected by acidification in the Czech Republic. Soil Science and Plant Nutrition 51: 745-749.

ter Braak CJF \& Šmilauer P (2012) CANOCO 5 Reference Manual and Cano Draw for Windows. User's guide to Canoco for Windows: software for canonical community ordination. Ithaca, New York: Microcomputer Power.

Brang P, Schönenberger W, Frehner M, Schwitter R, Thormann JJ \& Wasser B (2006) Management of protection forests in the European Alps: an overview. Forest Snow and Landscape Research 80: 23-44.

Braun S, Thomas VFD, Quiring R \& Flüeckiger W (2010) Does nitrogen deposition increase forest production? The role of phosphorus. Environmental Pollution 158: 2043-2052.

Bytnerowicz A, Omasa K \& Paoletti E (2007) Integrated effects of air pollution and climate change on forests: A northern hemisphere perspective. Environmental Pollution 147: 438-445.

Campioli M, Vincke C, Jonard M, Kint V, Demaree G \& Ponette Q (2012) Current status and predicted impact of climate change on forest production and biogeochemistry in the temperate oceanic European zone: review and prospects for Belgium as a case study. Journal of Forest Research 17: 1-18. 
Cook ER \& Kairiukstis L (1990) Methods of dendrochronology. Kluwer Academic Publishing, Dordrecht.

Cukor J, Vacek Z, Linda R, Sharma RP \& Vacek S (2019a) Afforested farmland vs. forestland: Effects of bark stripping by Cervus elaphus and climate on production potential and structure of $\mathrm{Pi}$ cea abies forests. PloS ONE 14: e0221082.

Cukor J, Vacek Z, Linda R, Vacek S, Marada P, Šimůnek V \& Havránek F (2019b) Effects of bark stripping on timber production and structure of Norway spruce forests in relation to climatic factors. Forests 10: 320.

Cukor J, Zeidler A, Vacek Z, Vacek S, Šimůnek V \& Gallo V (2020) Comparison of growth and wood quality of Norway spruce and European larch: effect of previous land use. European Journal of Forest Research. doi:10.1007/s10342-020-01259-7.

Dittmar C \& Elling W (2004) Radial growth of Norway spruce [Picea abies (L.) Karst.] at the Coulissenhieb Site in relation to environmental conditions and comparison with sites in the Fichtelgebirge and Erzgebirge. Ecological Studies 172: 291-311.

Dobbertin M (2005) Tree growth as indicator of tree vitality and of tree reaction to environmental stress: a review. European Journal of Forest Research 124: 319-333.

Dorotovič I, Louzada JL, Rodrigues JC \& Karlovský $\mathrm{V}$ (2014) Impact of solar activity on the growth of pine trees: case study. European Journal of Forest Research 133: 639-648.

Eastaugh CS, Pötzelsberger E \& Hasenauer H (2011) Assessing the impacts of climate change and nitrogen deposition on Norway spruce (Picea abies L. Karst) growth in Austria with BIOME-BGC. Tree Physiology 31: 262-274.

Etzold S, Waldner P, Thimonier A, Schmitt M \& Dobbertin M (2014) Tree growth in Swiss forests between 1995 and 2010 in relation to climate and stand conditions: Recent disturbances matter. Forest Ecology Management 311: 41-55.

Fabiánek P, Hellebrandová K \& Čapek M (2012) Monitoring of defoliation in forest stands of the Czech Republic and its comparison with results of defoliation monitoring in other European countries. Journal of Forest Science 58: 193-202.

Feliksik E (1972) Dendroclimatic studies on spruce (Picea excelsa L.): Part I. Studies of spruce in Gasienicowy Forest in the Tatra Mountains. Acta Agraria et Silvestria, Series Silvestris 12: 39-70.

Feliksik E (1995) Dendrological monitoring of the treat to the forests of Western Beskids created by industrial immission. The Beskids Bulletin 7: 23-34.

Fernandez CW, Heckman K, Kolka R \& Kennedy PG (2019) Melanin mitigates the accelerated decay of mycorrhizal necromass with peatland warming. Ecology Letters 22: 498-505.

Fritts HC (1976) Tree rings and climate. Academic Press Inc.

Ge ZM, Kellomäki S, Peltola H, Zhou X, Wang KY \& Väisänen H (2011) Impacts of changing climate on the productivity of Norway spruce dominant stands with a mixture of Scots pine and birch in relation to water availability in southern and northern Finland. Tree Physiology 31: 323-338.

Griffiths NA \& Sebestyen SD (2016) Temporal dynamics in the vertical profiles of peat porewater chemistry in a northern peatland. Wetlands 36: 1119-1130.

Grundmann BM, Bolte A, Bonn S \& Roloff A (2011) Impact of climatic variation on growth of Fagus sylvatica and Picea abies in Southern Sweden. Scandinavian Journal of Forest Research 26: 64-71.

Hůnová I, Šantroch J \& Ostatnická J (2004) Ambient air quality and deposition trends at rural stations in the Czech Republic during 1993-2001. Atmospheric Environment 38: 887-898.

Hůnová I, Maznová J \& Kurfürst P (2014) Trends in atmospheric deposition fluxes of sulphur and nitrogen in Czech forests. Environmental Pollution 184: 668-675.

Churkina G, Trusilova K, Vetter M \& Dentener F (2007) Contributions of nitrogen deposition and forest regrowth to terrestrial carbon uptake. Carbon Balance and Management 2: 5.

Jirgle J, Kučera J, Tichý J \& Materna J (1983) Poškození lesů v Jizerských horách imisemi. Zprávy lesnického výzkumu 28: 16-24.

Jolly WM, Dobbertin M, Zimmermann NE \& Reichstein M (2005) Divergent vegetation growth responses to the 2003 heat wave in the Swiss Alps. Geophysical Research Letters 32: 18.

Kirschbaum MUF (2000) Forest growth and species distribution in a changing climate. Tree Physiology 20: 309-322.

Klisz M, Jastrzębowski S, Ukalski K, Ukalska J \& Przybylski P (2017) Adaptation of Norway spruce populations in Europe: a case study from northern Poland. New Zealand Journal of Forestry Science 47: 8 .

Knibbe B (2007) PAST 4: personal analysis system for treering research, Version 4.2. SCIEM, Vienna.

Koprowski M \& Zielski A (2006) Dendrochronology of Norway spruce (Picea abies (L.) Karst.) from two range centres in lowland Poland. Trees 20: 383-390.

Köppen WP (1936) Das Geographische System der Klimate. Handbuch der Klimatologie, Gebrüder Borntraeger, Berlin.

Král J, Vacek S, Vacek Z, Putalová T, Bulušek D \& Štefančík I (2015) Structure, development and health status of spruce forests affected by air pollution 
in the western Krkonoše Mts. in 1979-2014. Lesnícký časopis - Forestry Journal 61: 175-187.

Králíček I, Vacek Z, Vacek S, Remeš J, Bulušek D, Král J, Štefančík I \& Putalová T (2017) Dynamics and structure of mountain autochthonous sprucebeech forests: impact of hilltop phenomenon, air pollutants and climate. Dendrobiology 77: 119137.

Krassovski MB, Riggs JS, Hook LA, Nettles WR, Hanson PJ \& Boden TA (2015) A comprehensive data acquisition and management system for an ecosystem-scale peatland warming and elevated CO2 experiment. Geoscientific Instrumentation, Methods and Data Systems 4: 203-213.

Krejčí F, Vacek S, Bílek L, Mikeska M, Hejcmanová P \& Vacek Z (2013) The effects of climatic conditions and forest site types on disintegration rates in Picea abies occurring at the Modrava Peat Bogs in the Šumava National Park. Dendrobiology 70: 35-44.

Kroupová M (2002) Dendroecological study of spruce growth inregions under long-term air pollution load. Journal of Forest Science 48: 536-548.

Laubhann D, Sterba H, Reinds GJ \& De Vries W (2009) The impact of atmospheric deposition and climate on forest growth in European monitoring plots: an individual tree growth model. Forest Ecology and Management 258: 1751-1761.

Lindner M, Maroschek M, Netherer S, Kremer A, Barbati A, Garcia-Gonzalo J, Seidl R, Delzon S, Corona P, Kolström M, Lexer MJ \& Marchetti M (2010) Climate change impacts, adaptive capacity, and vulnerability of European forest ecosystems. Forest Ecology and Management 259: 698-709.

Lomský B \& Šrámek V (2002) Damage of the forest stands in 1990s.: $\mathrm{SO}_{2}$-pollution and forests decline in the Ore Mountains (ed. by B Lomský, J Materna \& H Pfanz) VÚLHM, Jíloviště-Strnady, pp. 139-155.

Lomský B, Šrámek V \& Novotný R (2012) Changes in the air pollution load in the Jizera Mts.: effects on the health status and mineral nutrition of the young Norway spruce stands. European Journal of Forest Research 131: 757-771.

Lorenz M (1995) International co-operative programme on assessment and monitoring of air pollution effects on forests - ICP forests. Water, Air, \& Soil Pollution 85: 1221-1226.

Lorenz M, Nagel HD, Granke O \& Kraft P (2008) Critical loads and their exceedances at intensive monitoring sites in Europe. Environmental Pollution 155: 426-435.

Mäkinen H, Nöjd P, Kahle H-P, Neumann U, Tveite B, Mielikäinen K, Röhle H \& Spiecker H (2003) Large-scale climatic variability and radial increment variation of Picea abies (L.) Karst. in central and northern Europe. Trees 17: 173-184.
Máliš F, Vladovič J, Čaboun V \& Vodálová A (2010) The influence of Picea abies on herb vegetation in forest plant communities of the Veporské vrchy Mts. Journal of Forest Science 56: 58-67.

Matějka K, Vacek S \& Podrázský V (2010) Development of forest soils in the Krkonoše Mts. in the period 1980-2009. Journal of Forest Science 56: 485-504.

Materna J (1960) The nutrition of Spruce on raised peat-bogs in Bohemia. Lesnictvi 6: 495-504.

Mazurski KR (1986) The destruction of forests in the Polish Sudetes Mountains by industrial emissions. Forest Ecology and Management 17: 303315.

McPartland MY, Kane ES, Falkowski MJ, Kolka R, Turetsky MR, Palik B \& Montgomery RA (2019) The response of boreal peatland community composition and NDVI to hydrologic change, warming and elevated carbon dioxide. Global Change Biology 25: 93-107

Meehl GA, Stocker TF \& Collins WD (2007) Global climate projections: Climate change 2007: The physical science basis. Contribution of working group I to the fourth assessment report of the intergovernmental panel on climate change (ed. by S Solomon, D Qin, M Manning, Z Chen, M Marquis, KB Averyt, $M$ Tignor, HL Miller) Cambridge University Press, Cambridge, pp. 747-845.

van der Meer PJ, Jorritsma ITM \& Kramer K (2002) Assessing climate change effects on long-term forest development: adjusting growth, phenology, and seed production in a gap model. Forest Ecology and Management 162: 39-52.

Mencuccini M, Martinez-Vilalta J, Vanderklein D, Hamid HA, Korakaki E, Lee S \& Michiels B (2005) Size-mediated ageing reduces vigour in trees. Ecology Letters 8: 1183-1190.

Meyer FD \& Bräker OU (2001) Climate response in dominant and suppressed spruce trees, Picea abies (L.) Karst., on subalpine and lower montana site in Switzerland. Ecoscience 8: 105-114.

Mikulenka P, Prokůpková A, Vacek Z, Vacek S, Bulušek D, Simon J, Šimůnek V \& Hájek V (2020) Effect of climate and air pollution on radial growth of mixed forests: Abies alba Mill. vs. Picea abies (L.) Karst. Central European Forestry Journal 66: 23-36.

Modrzyński J (2003) Defoliation of older Norway spruce (Picea abies /L./ Karst.) stand in the Polish Sudety and Carpathian mountains. Forest Ecology and Management 181: 289-299.

Petritsch R \& Hasenauer H (2009) Tägliche Wetterdaten im 1 km Raster von 1960 bis 2008 über Österreich. Austrian Journal of Forest Science 126: 215-225.

Pichler P \& Oberhuber W (2007) Radial growth response of coniferous forest trees in an inner Al- 
pine environment to heatwave in 2003. Forest Ecology and Management 242: 688-699.

Podrázský V, Vacek S, Remeš J \& Ulbrichová I (2005) Application of Mg-fertilizers to prevent and to decrease Norway spruce yellowing. Journal of Forest Science 51: Special Issue: 43-47.

Putalová T, Vacek Z, Vacek S, Štefančík I, Bulušek D \& Král J (2019) Tree-ring widths as an indicator of air pollution stress and climate conditions in different Norway spruce forest stands in the Krkonoše Mts. Central European Forestry Journal 65: 21-33.

Quitt E (1971) Klimatické oblasti Československa. Academia, Praha.

Remeš J, Bílek L, Novák J, Vacek Z, Vacek S, Putalová T \& Koubek L (2015) Diameter increment of beech in relation to social position of trees, climate characteristics and thinning intensity. Journal of Forest Science 61: 456-464.

Renaud V \& Rebetez M (2009) Comparison between open-site and below-canopy climatic conditions in Switzerland during the exceptionally hot summer of 2003. Agricultural and Forest Meteorology 149: 873-880.

Rybníček K (2000) Present results of vegetation and habitat monitoring in mountain bogs of the Jizerské hory Mts., 1991-1998. Příroda 17: 101-108.

Rybníček M, Čermák P, Kolář T, Přemyslovská E \& Žid T (2009) Influence of temperatures and precipitation on radial increment of Orlické hory Mts. spruce stands at altitudes over $800 \mathrm{~m}$ a.s.l. Journal of Forest Science 55: 257-263.

Sharma RP, Vacek Z, Vacek S, Jansa V \& Kučera M (2017) Modelling individual tree diameter growth for Norway spruce in the Czech Republic using a generalized algebraic difference approach. Journal of Forest Science 63: 227-238.

Sharma RP, Vacek Z \& Vacek S (2018) Generalized nonlinear mixed-effects individual tree crown ratio models for Norway spruce and European beech. Forests 9: 555.

Schelhaas MJ, Nabuurs GJ, Sonntag M \& Pussinen A (2002) Adding natural disturbances to a largescale forest scenario model and a case study for Switzerland. Forest Ecology and Management 167: 13-26.

Schulze ED, Lange OL \& Oren R (1989) Forest decline and air pollution: a study of spruce (Picea abies) on acid soils. Springer, Berlin.

Schuster R \& Oberhuber W (2013) Age-dependent climate-growth relationships and regeneration of Picea abies in a drought-prone mixed-coniferous forest in the Alps. Canadian Journal of Forest Research 43: 609-618.

Schweingruber FH, Eckstein D, Serre-Bachet F \& Bräker OU (1990) Identification, presentation and interpretation of event years and pointer years in dendrochronology. Dendrochronologia 8: 9-38.

Slanař J, Vacek Z, Vacek S, Bulušek D, Cukor J, Štefančík I, Bílek L \& Král J (2017) Long-term transformation of submontane spruce-beech forests in the Jizerské hory Mts.: dynamics of natural regeneration. Central European Forestry Journal 63: 213-225.

Slovik S, Siegmund A, Kindermann G, Reiblieng R \& Baláz Á (1995) Stomatal $\mathrm{SO}_{2}$ uptake and sulphate accumulation in needles of Norway spruce stands (Picea abies) in central Europe: Nutrient Uptake and Cycling in Forest Ecosystems (ed. by LO Nilsson, RF Hüttl, UT Johansson) Kluwer Academic Publishers, Dordrecht, pp. 405-419.

Solberg S, Dobbertin M, Reinds GJ, Lange H, Andreassen K, Garcia Fernandez P, Hildingsson A \& de Vries W (2009) Analyses of the impact of ganges in atmospheric deposition and climate on forest growth in European monitoring plots: a stand growth approach. Forest Ecology and Management 258: 1735-1750.

Staszewski T, Kubiesa P \& Łukasik W (2012) Response of spruce stands in national parks of southern Poland to air pollution in 1998-2005. European Journal of Forest Research 131: 11631173.

Šimůnek V, Vacek Z, Vacek S, Králíček I \& Vančura K (2019) Growth variability of European beech (Fagus sylvatica L.) natural forests: Dendroclimatic study from Krkonoše National Park. Central European Forestry Journal 65: 92-102.

Šrámek V, Materna J, Novotný R \& Fadrhonsová $\mathrm{V}$ (2006) Effect of forest liming in the Western Krušné hory Mts. Journal of Forest Science 52: 45-51.

Šrámek V, Novotný R, Bednářová E \& Uhlírová $H$ (2007) Monitoring of ozone risk for forest in the Czech Republic: preliminary results. Scientific. Scientific World Journal 7: 78-83.

Šrámek V, Slodičák M, Lomský B, Balcar V, Kulhavý J, Hadaš P, Pulkráb K, Šišák L, Pěnička L \& Sloup M (2008) The Ore Mountains: will successive recovery of forests from lethal disease be successful? Mountain Research and Development 28: 216-221.

Šrámek V, Novotný R \& Fadrhonsová V (2015) Decay of Norway spruce stands and quality of forest soils in the region of northern Moravia and Silesia. Zprávy lesnického výzkumu 60: 147-153.

Štícha V, Sharma RP, Vacek Z, Vacek S \& Nuhlíček O (2019) Timber and branch volume prediction: Effects of stand and site characteristics on dendromass and timber-to-branch volume ratio of Norway spruce in managed forests. Forests 10: 144. 
Tesař V \& Temmlová B (1971) Olistění stromů jako kritérium pro hodnocení stavu porostů v imisním území. Lesnictví 17: 1017-1032.

Thiele JC, Nuske RS, Ahrends B, Panferov O, Albert M, Staupendahl K, Junghansb U, Jansen M \& Saborowski J (2017) Climate change impact assessment - A simulation experiment with Norway spruce for a forest district in Central Europe. Ecological Modelling 346: 30-47.

Thornthwaite CW \& Mather JR (1957) Instructions and tables for computing potential evapotranspiration and water balance. Laboratory of Climatology.

Tolasz R, Míková T, Valeriánová A \& Voženílek V (2007) Climate atlas of Czechia. Czech Hydrometeorological Institute, Praha.

Tumajer J \& Treml V (2017) Influence of artificial alteration of groundwater level on vessel lumen area and tree-ring width of Quercus robur. Trees 31: 1945-1957.

Ulbrichová I \& Šimková I (2007) Natural regeneration of the spruce on the selected wet sites in the Jizerské Mountains. Scientia Agriculturae Bohemica 38: 135-141.

UNECE (2005) Sampling and analysis of needles and leaves: Manual on methods and criteria for harmonized sampling, assessment, monitoring and analysis of the effects of air pollution on forests, UNECE ICP Forests Programme Co-ordinating Centre, Hamburg, pp. 1-19.

Vacek S, Zingari PC, Jeník J, Vančura K, Simon J \& Smejkal J (2003) Mountain forests of the Czech Republic. Ministry of agriculture, Prague.

Vacek S, Podrázský V, Hejcman M \& Remeš J (2006) Effect of $\mathrm{Mg}$ fertilization on yellowing disease of Norway spruce at higher elevations of the Šumava Mts., Czech Republic. Journal of Forest Science 52: 474-481.

Vacek S, Semelová V, Remeš J \& Podrázský V (2009) Effect of soil chemical properties on growth, foliation and nutrition of Norway spruce stand affected by yellowing in the Bohemian Forest Mts., Czech Republic. European Journal of Forest Research 128: 367-375.

Vacek S \& Matějka K (2010) Health status of forest stands on PRP in the Krkonoše Mts. Journal of Forest Science 56: 555-569.

Vacek S, Hejcmanová P \& Hejcman M (2012) Vegetative reproduction of Picea abies by artificial layering at the ecotone of the alpine timberline in the Giant (Krkonoše) Mountains, Czech Republic. Forest Ecology and Management 263: 199-207.

Vacek S, Bílek L, Schwarz O, Hejcmanová P \& Mikeska M (2013) Effect of air pollution on the health status of spruce stands - a case study in the Krkonoše Mountains, Czech Republic. Mountain Research and Development 33: 40-50.
Vacek S, Hůnová I, Vacek Z, Hejcmanová P, Podrázský V, Král J, Putalová T \& Moser WK (2015) Effects of air pollution and climatic factors on Norway spruce forests in the Orlické hory Mts. (Czech Republic), 1979-2014. European Journal of Forest Research 134: 1127-1142.

Vacek S, Vacek Z, Bílek L, Simon J, Remeš J, Hůnová I, Král J, Putalová T \& Mikeska M (2016) Structure, regeneration and growth of Scots pine (Pinus sylvestris L.) stands with respect to changing climate and environmental pollution. Silva Fennica 50: 1564.

Vacek S, Prokůpková A, Vacek Z, Bulušek D, Šimůnek V, Králíček I, Prausová R \& Hájek V (2019c) Growth response of mixed beech forests to climate change, various management and game pressure in Central Europe. Journal of Forest Science 65: 331-345.

Vacek S, Vacek Z, Ulbrichová I, Remeš J, Podrázský V, Vach M, Bulušek D, Král J \& Putalová T (2019a) The Effects of Fertilization on the Health Status, Nutrition and Growth of Norway Spruce Forests with Yellowing Symptoms. Scandinavian Journal of Forest Research 34: 267-281.

Vacek Z, Vacek S, Podrázský V, Král J, Bulušek D, Putalová T, Baláš M, Kalousková I \& Schwarz O (2016) Structural diversity and production of alder stands on former agricultural land at high altitudes. Dendrobiology 75: 31-44.

Vacek Z, Vacek S, Bulušek D, Podrázský V, Remeš J, Král J \& Putalová T (2017) Effect of fungal pathogens and climatic factors on production, biodiversity and health status of ash mountain forests. Dendrobiology 77: 1755-1315.

Vacek Z, Vacek S, Slanař J, Bílek L, Bulušek D, Štefančík I, Králíček I \& Vančura K (2019b) Adaption of Norway spruce and European beech forests under climate change: from resistance to closeto-nature silviculture. Central European Forestry Journal 65: 129-144.

Vejpustková M, Zahradník D, Šrámek V \& Fadrhonsová V (2004) Growth trends of spruce in the Orlické hory Mts. Journal of Forest Science 50: 67-77.

Vesecký A, Briedoň V, Karský V \& Petrovič Š (1961) Podnebí Československé socialistické republiky. Tabulky. Hydrometeorologický ústav, Praha.

Viewegh J, Kusbach A \& Mikeska M (2003) Czech forest ecosystem classification. Journal of Forest Science 49: 74-82.

Vitali V, Büntgen U, \& Bauhus J (2017) Silver fir and Douglas fir are more tolerant to extreme droughts than Norway spruce in south-western Germany. Global Change Biology 23: 5108-5119.

de Vries W, Solberg S, Dobbertin M, Sterba D, Laubhann $D$, van Oijen $M$, Evans C, Gundersen P, Kros J, Wamelink GWW, Reinds GJ \& Suttonet 
MA (2009) The impact of nitrogen deposition on carbon sequestration by European forests and heathlands. Forest Ecology and Management 258: 1814-1823.

Wilczyński S \& Feliksik E (2005) Disturbances in variation of the annual ring width of Norway spruce in the Polish Western Beskids Mountains. Journal of Forest Science 51: 539-547.

Yamaguchi K (1991) Event history analysis. Sage Publications, London.

Zahradník D, Vacek S, Bílek L, Nosková I \& Vacek Z (2010) Horizontal structure of forest stands on permanent research plots in the Krkonoše Mts. and its development. Journal of Forest Science 56: 531-540.

Zimmermann J, Hauck M, Dulamsuren C \& Leuschner C (2015) Climate warming-related growth decline affects Fagus sylvatica, but not other broadleaved tree species in Central European mixed forests. Ecosystems 18: 560-572.

Žid T \& Čermák P (2008) Health condition of spruce stands in the Orlické hory Mts. in relation to -climatic, anthropogenic and stand factors. Journal of Forest Science 53: 1-12. 